\title{
The Climate of Incivility in Philippine Daily Inquirer's Social Media Environment
}

\author{
Ma. Rosel S. San Pascual
}

My study describes the atmosphere of incivility in a specific local online setting by looking at the incidence of incivility in the reader comments field of Philippine Daily Inquirer's (PDI) news website and official Facebook page. Even though studies about online incivility in deliberative intercourse are not new, there is a dearth in scholarly research examining incivility in the context of local online discourse. A total of 5,255 reader comments were gathered from PDI's top trending news article of the day over a seven-day constructed week sampling, which covered a total of seven top trending news articles selected during September and October 2017. Findings reveal that $76.6 \%$ of the total comments contained at least one form of incivility and it was found to be more present during the first 12 hours after an article's online posting. The most popular forms of incivility across comment levels were character assassination, stand assassination, mockery, and name-calling and were typically directed at others outside the discussion thread. While there was no significant difference between PDI's website and Facebook page in terms of forms and timeline of incivility, a higher density of incivility was found in its website. Moderation of comments is thus recommended as well as media and information literacy campaigns to address the incidence of online incivility.

Keywords: online incivility, online discourse, social media, reader comments field

\section{Exploring Incivility in Online Public Discourse Environments}

Deliberative democracy argues that the democratic potential of various publics deliberating on matters do have implications on the state of the public's welfare (Burns, Scholzman, \& Verba, 2001; Dahlgren, 2009). It encourages heterogeneous opinions to be expressed, heard, and deliberated on so that decisions concerning the public's welfare integrate various voices-from dominant, alternative, and counter publics-and not just the articulations of the prevailing order (Chen \& Lu, 2017; Papacharissi, 2004). Therefore, deliberative democracy innately recognizes that disagreements are commonplace as diverse and divergent opinions are given space in the public sphere (Chen, 2017; Chen \& Lu, 2017; Dahlgren, 2009; Mutz \& Reeves, 2005).

Given social media's ubiquity and interactivity (Lievrouw \& Silverstone, 2006), an omnipresent toxic social media environment could encourage more noxious engagement, which could further compromise the space wherein multiple heterogeneous voices are supposedly respectfully 
expressed, heard, and deliberated on. Thus, interests about online incivility revolve around its consequence on discursive participation and its impact on deliberative democracy (e.g., Brooks \& Geer, 2007; Coe, Kenski, \& Rains, 2014; Gervais, 2014; Mutz \& Reeves, 2005; Papacharissi, 2004; Rowe, 2013; Stryker, Conway, \& Danielson, 2014). Kevin Coe, Kate Kenski, and Stephen A. Rains (2014) described online incivility as "features of discussion that convey an unnecessarily disrespectful tone toward the discussion forum, its participants, or its topics" (p. 3). Disrespect is considered unnecessary when disagreements in discussion may be carried out without hostility and mockery (Brooks \& Greer, 2007; Sapiro, 1999). Thus, incivility denigrates the core value of freedom of speech and expression, which ultimately dishonors the "collective traditions of democracy" (Papacharissi, 2004, p. 9). As such, there is a growing sentiment to address the apparent rise in the occurrence of incivility in online public discourse.

While public discourse incivility is not a recent phenomenon, it has become undeniably more pronounced in contemporary online public sphere (Chen, 2017; Sapiro, 1999). Indeed, the civic space that has opened the floodgates to a wider range of publics to engage in discursive interaction is also the very same space where intolerance and insolence have burgeoned. Thus said, individuals are exposed to supporting, dissenting, or neither supporting nor dissenting opinions that may either be civilly or uncivilly expressed in social media.

Before the turn of the twenty-first century, Virginia Sapiro (1999) documented concerns about a civility crisis in the US pointing out that if such a decline was indeed happening, then it would have adverse consequences on the functioning of democracy by "making members of society less fit for engaging in democratic politics, and less able to deliberate with each other democratically" (p. 3). Scholars noted that it is incivility in political discussion, and not conflict per se, that engenders negative attitudes (Mutz \& Reeves, 2005).

However, individuals' subjective notions of the threshold of incivility as violations in norms of respect vary (Montgomery, Kane, \& Vance, 2004). For instance, in their study of incivility in the workplace, Kathleen Montgomery, Kathleen Kane, and Charles M. Vance (2004) observed that men and women have varying limits at which they perceive a breach in the norms of respect, which they attributed to gendered differences in interpersonal empathy and sensitivity. The gendered difference in threshold is also compounded by the interaction of gender and race (Montgomery, Kane, \& Vance, 2004).

Then again, civility and incivility could be strategically employed for political ends (Herbst, 2010). For instance, Herbert Marcuse (as cited by Herbst, 2010) supported forms of incivility, such as harsh interference with 
the free speech of others, if such interferences promoted social movements and justice. Hence, while there is a general consensus in the literature that incivility puts democracy at risk (for instance, Coe, Kenski, \& Rains, 2014; Papacharissi, 2004), Susan Herbst (2010) argued differently:

One question that arises when we treat civility and incivility as strategic tools is whether they are good or bad, helpful or hurtful for democracy. An easy answer is the one we so often see in the scholarly politics literature: incivility is destructive and blocks proper democratic debate. I find this a banal and unsophisticated answer, one that ignores the reality of politics, communication culture, and the social environment of the twenty-first century. In this book, I do not dodge this question, but there is no definitive answer to it either, and we would be dishonest to grandstand on it. It depends entirely on issue and situational context, and is closely tied to ideology and passion (p. 9).

Myopic as it may seem to Herbst (2010), I will nonetheless follow Zizi Papacharissi's (2004) assertion that incivility is an affront to democracy when it compromises the democratic potential of political discourse. Gina Masullo Chen (2017) even argues for the "zone of deliberative moments" the "sweet spot that is not so polite that it prohibits disagreement or discord but not so nasty that it makes rational speech impossible" (p. 177).

\section{Research Focus}

Even though studies about online incivility in deliberative intercourse is not new (e.g., Anderson, Brossard, Scheufele, Xenos, Ladwig, 2014; Coe, Kenski, \& Rains, 2014; Diakopoulos \& Naaman, 2011; Rosner \& Kramer, 2016), there is a dearth in scholarly research examining incivility in the context of local online discourse. Thus, I have gathered evidence about the occurrence of incivility, or lack thereof, in a specific online context.

Philippine Daily Inquirer or PDI has been in existence for more than three decades. Its official website chronicles that the maiden issue of its broadsheet was released in December 1985 and, 12 years later, its news website made its debut in October 1997, the first in the Philippine broadsheet industry to establish an online presence ("History," n.d.). With a commitment to deliver "Balanced news, fearless views," it has amassed over 500 awards and citations ("Company," n.d.). Its website cites Nielsen 2016 data that PDI accounts for $47 \%$ of the broadsheet readership share ("Our Market," n.d.) and notes that its news site reaches over a million page views daily ("Company," n.d.), thus maintaining the recognition as the country's 
leading newspaper and holding the record as the country's top news website. $P D I$ recognizes that its readers primarily belong to socio-income segments $\mathrm{AB}$ and $\mathrm{C}$ and classifies its core reader markets into emerging adults (2534 years old), mature adults (35-45 years old), and early empty nesters (45 years old and above) ("Our Market," n.d.). PDI has enabled its readers to engage in online public discourse via their logged-in social media accounts such as Facebook, Twitter, Google, or Disqus.

Given the volume of $P D I$ s reader traffic, studying the incidence of incivility in the reader comments field of $P D I$ 's news website and official Facebook page would offer an evidence-based description of the extent of incivility that PDI's online public is exposed to. My study thus attempts to answer this research question: What is the climate of incivility in the reader comments section of PDI's news website and official Facebook page? I have tackled my study's key question by looking at the incidences of incivility in the reader comments field of PDI's news website and official Facebook page, thereby addressing the following objectives:

1. To describe the general landscape of incivility in PDI's reader comments section.

a. To identify the forms of incivility that occur in the reader comments section of $P D I$ 's news website and official Facebook page, their location in the comment thread, and to whom they are directed.

b. To plot the timeline of occurrence of the most popular forms of incivility in the reader comments section of PDI's news website and official Facebook page.

c. To determine the density of incivility in the reader comments section of $P D I$ 's news website and official Facebook page.

2. To find out if there is a difference in the forms of incivility, timeline of occurrence of the most popular forms of incivility, and density of incivility between $P D I$ s news website and official Facebook page.

This paper is a component of a larger research project on Investigating Online Incivility and Its Consequence on Online Discourse Engagement. It focuses on addressing the descriptive component of the project, which aims to describe the climate of incivility in two online public discourse environments through content analysis. Meanwhile, the other component of the research project focuses on addressing the explanatory component of the project, which aims to causally explain the democratic consequences of exposure to either a civil or uncivil discourse environment through online experiment. Hence, message effect questions on the link between individuals' online opinion exposure and their consequent participation in 
online public discourse will be addressed in the other papers coming out from the experiment component of the larger research project.

\section{Defining and Describing the Extent of Incivility}

Scholars have some overlaps in their conceptualization of incivility as a violation of the norms of respectful engagement among discourse participants, which could then possibly undermine the democratic potential of political discourse (Coe, Kenski, \& Rains, 2014; Gervais, 2014; Papacharissi, 2004; Rowe, 2013; Stryker, Conway, \& Danielson, 2014). Robin Stryker, Bethany Conway, and J Taylor Danielson (2014) wrote: "while civility and deliberation are analytically distinct concepts, elements of incivility have been presumed damaging to the quality and effectiveness of ongoing political discourse" (p. 23). Grounded on this notion of incivility, my research adheres to Papacharissi's (2004) conceptualization of incivility in the context of its democracy-compromising consequences.

However, Stryker, Conway, and Danielson (2014) observed that while scholars more or less share similar conceptualization of incivility, they differ in its operationalization: "Overall, a pattern of substantial overlap in conceptualization, paired with the absence of full consensus, is common in the empirical literature, and has produced a series of different yet interrelated measures" (p.7). My study thus offers a synthesized operationalization of incivility proposed by Coe, Kenski, and Rains (2014); Bryan T. Gervais (2014); Ian Rowe (2013); and Stryker, Conway, and Danielson's (2014), which I organized according to the latter set of authors' multidimensional construct of political incivility, to come up with a matrix of operational definition of the forms of incivility [Table 1].

Table 1. Operational Definition of the Forms of Incivility

\begin{tabular}{|c|c|c|}
\hline $\begin{array}{l}\quad \text { Dimension 1 } \\
\text { Utterance Incivility } \\
\text { Covers statements that are } \\
\text { impertinent and offensive } \\
\text { (Stryker, Conway, \& Danielson, } \\
\text { 2014) }\end{array}$ & $\begin{array}{l}\quad \text { Dimension 2 } \\
\quad \text { Discursive Incivility } \\
\text { Covers statements that could } \\
\text { potentially "shut down or } \\
\text { detract from inclusive and } \\
\text { ongoing political discussion" } \\
\text { (Stryker, Conway, \& Danielson, } \\
\text { 2014, p. 23). }\end{array}$ & $\begin{array}{l}\qquad \frac{\text { Dimension } 3}{\text { Deception }} \\
\text { Covers statements that are } \\
\text { inaccurate or incomplete } \\
\text { (Stryker, Conway, \& Danielson, } \\
\text { 2014) }\end{array}$ \\
\hline $\begin{array}{l}\text { Name-calling } \\
\text { Use of derogatory names to } \\
\text { express distaste or contempt } \\
\text { (Gervais, 2014; Rowe, 2013; } \\
\text { Stryker, Conway, \& Danielson, } \\
\text { 2014) }\end{array}$ & $\begin{array}{l}\text { Threat to freedom of speech } \\
\text { and expression } \\
\text { Threatening an opponent's } \\
\text { freedom to voice an opinion } \\
\text { (Papacharissi, 2004) }\end{array}$ & $\begin{array}{l}\text { Lying } \\
\text { Intentionally making false or } \\
\text { misleading statements (Gervais, } \\
\text { 2014; Stryker, Conway, \& } \\
\text { Danielson, 2014) }\end{array}$ \\
\hline
\end{tabular}




\begin{tabular}{|c|c|c|}
\hline $\begin{array}{l}\text { Character assassination } \\
\text { Attack on the reputation } \\
\text { or integrity of someone or } \\
\text { something (Gervais, 2014; Rowe, } \\
\text { 2013) }\end{array}$ & $\begin{array}{l}\text { Threat to person } \\
\text { Threatening an opponent } \\
\text { with physical harm and } \\
\text { encouraging others to inflict } \\
\text { physical harm (Stryker, } \\
\text { Conway, \& Danielson, 2014) }\end{array}$ & $\begin{array}{l}\text { Hyperbole } \\
\text { Making exaggerated } \\
\text { statements that misrepresent } \\
\text { or obscure the truth (Gervais, } \\
\text { 2014; Rowe, 2013; Stryker, } \\
\text { Conway, \& Danielson, 2014) }\end{array}$ \\
\hline $\begin{array}{l}\text { Stand assassination } \\
\text { Attack on an opponent's stand } \\
\text { on issues (Stryker, Conway, \& } \\
\text { Danielson, 2014) }\end{array}$ & $\begin{array}{l}\text { Refusal to listen } \\
\text { Refusing to listen to an } \\
\text { opponent's viewpoints } \\
\text { (Stryker, Conway, \& Danielson, } \\
\text { 2014) }\end{array}$ & $\begin{array}{l}\text { Lack of evidence } \\
\text { Failing to provide reasons and } \\
\text { evidence to support one's } \\
\text { opinion (Stryker, Conway, \& } \\
\text { Danielson, 2014) }\end{array}$ \\
\hline $\begin{array}{l}\text { Stereotyping } \\
\text { Using labels to associate } \\
\text { an opponent with a group } \\
\text { (Papacharissi, 2004; Rowe, 2013) }\end{array}$ & & \\
\hline $\begin{array}{l}\text { Demonize } \\
\text { Demonizing an opponent } \\
\text { (Stryker, Conway, \& Danielson, } \\
\text { 2014) }\end{array}$ & & \\
\hline $\begin{array}{l}\text { Mockery } \\
\text { Jeering at an opponent (Gervais, } \\
\text { 2014; Stryker, Conway, \& } \\
\text { Danielson, 2014) }\end{array}$ & & \\
\hline $\begin{array}{l}\text { Vulgarity } \\
\text { Use of profane or obscene } \\
\text { language (Coe, Kenski, \& Rains, } \\
\text { 2014; Rowe, 2013; Stryker, } \\
\text { Conway, \& Danielson, 2014) }\end{array}$ & & \\
\hline $\begin{array}{l}\text { Slur } \\
\text { Use of racial, sexist, ethnic, or } \\
\text { religious insult (Stryker, Conway, } \\
\text { \& Danielson, 2014) }\end{array}$ & & \\
\hline $\begin{array}{l}\text { Shout } \\
\text { Use of uppercase letters or } \\
\text { multiple exclamation points } \\
\text { (Gervais, 2014; Stryker, Conway, } \\
\text { \& Danielson, 2014) }\end{array}$ & & \\
\hline $\begin{array}{l}\text { Pejorative speech } \\
\text { Disparaging remarks about } \\
\text { an opponent's manner of } \\
\text { expression (Gervais, 2014; Coe, } \\
\text { Kenski, \& Rains, 2014; Rowe, } \\
\text { 2013) }\end{array}$ & & \\
\hline
\end{tabular}




\section{Aspersion}

Disparaging words directed at an idea, plan, policy, or behavior

(Coe, Kenski, \& Rains, 2014)

My decision to cover all forms of incivility identified in the literature, even though Papacharissi (2004) may consider some of these forms as mere impoliteness, is based on the goals of the larger research project where this current study is a component of: to test whether these forms will actually have implications on online opinion expression or concealment. If any of these forms of incivility creates silencing effect, then it generates consequences on deliberative democracy. Thus, I purposely included all forms of incivility in the content analysis as the experiment component of the larger project would actually test the democratic consequences of these forms of incivility on public discourse participation or withdrawal.

Nonetheless, to enhance the conceptual and contextual strength of the identified forms of incivility, a further description of the relative magnitude of these forms of incivility is a strongly recommended future research undertaking, one that would locally contextualize the conceptual nuances of each form of incivility, the degree of possible tolerability of the various forms of incivility, and array the forms of incivility on a spectrum of possibly increasing/decreasing degree of tolerability. In the interim, however, given that this is the first local study to make an inventory of the forms of incivility that may be present in the local online news environment, my study will make use of the forms of incivility identified and synthesized from extant literature.

Then again, my study also attempts to expand its description of the general landscape of incivility in PDI's reader comments section by going beyond identifying the forms of incivility that occur in the reader comments section of PDIs news website and official Facebook page. My study also seeks to identify the location of incivility in the comment thread-either as a main comment, as a response to the main comment (first-level comment), as a response to the first-level comment (second-level comment), or as a response to the second-level comment (third-level comment). Doing so would provide evidence if incivility indeed generates further incivility (San Pascual, 2019). As I have asserted in another paper, individuals exposed to an uncivil opinion environment are likely to participate uncivilly as well (San Pascual, 2019).

Furthermore, my study attempts to identify to whom the uncivil comment is directed-whether interpersonal (the comment was directed at fellow discussant in the thread), other-directed (the comment was directed 
at others outside the comments thread), both (the comment was directed at fellow discussant and others outside the comments thread), or neutral (the comment was not directed at anyone). Rowe's (2015) study traced the boldness of interpersonally directed comments to the anonymity that a platform offers, which consequently emboldens participants to direct their uncivil comment at their fellow forum discussants.

My study likewise aims to plot the timeline of occurrence of the most popular forms of incivility and to determine the density of incivility. Theories and literature on public opinion indicated that public opinion is temporally located (e.g., Antoci, Delfino, Paglieri, Panebianco, Sabatini, 2016; Dahlgren, 2009; Noelle-Neumann \& Petersen, 2004). Surprisingly, however, extant literature on political discourse incivility appears to have overlooked this interesting detail. My study thus attempts to furnish evidence on this underexamined aspect by charting the occurrence of incivility in PDI's reader comments fields.

Meanwhile, by applying Papacharissi's (2004) concept of incivility density, my study aims to compute the extent of incivility occurrence in $P D I$ 's reader comments fields. Density pertains to the magnitude of incivility occurrence within a given reader comments field (Papacharissi, 2004).

\section{Social Media Platform, Anonymity, and Online Disinhibited Behavior}

Online disinhibition pertains to people's less restrained behaviors online such that, online, they are able to express and perform things that they would not typically do offline (Suler, 2004). John Suler's Online Disinhibition Effect has often been cited in the literature when tracing the factors that push individuals, who perceive their opinions to be aligned with the minority, to speak up (Kwon \& Cho, 2015; Yun \& Park, 2011). Suler (2004) identified six factors that lead to less inhibited behaviors online: dissociative anonymity, invisibility, asynchronicity, solipsistic introjection, dissociative imagination, and minimization of status and authority. Among these factors, anonymity has been popularly incorporated in studies that investigated the silencing effect (e.g., Kwon \& Cho, 2015; Rosner \& Kramer, 2016).

Anonymity offers a cloak of invisibility. In a group setting, anonymity has been theorized to facilitate deindividuation among discourse participants, wherein individuals tend to be less conscious of their individuality so, instead of following conventional norms of behavior, individuals feel less constrained to regulate their behavior (Chang, 2008). In this manner, an anonymous social media environment is even more prime for deindividuation effect to take place, as anonymity, coupled with social media's characteristic ubiquity 
and interactivity (Lievrouw \& Silverstone, 2006), creates an ultimate petri dish for cultivating online disinhibited behaviors.

Several studies that investigated the causes of incivility in the online comments field linked the incidence of online incivility with the disinhibition effect of anonymity (e.g., Kwon \& Cho, 2015; Rosner \& Kramer, 2016; Yun \& Park, 2011). These studies clarified that anonymity need not be actual anonymity. Rather, it is the individual's perceived anonymity to others, also labeled as "self-anonymity", that potentially trigger disinhibited behaviors (Kwon \& Cho, 2015; Yun \& Park, 2011). As such, the use of pseudonyms could provide impressions of self-anonymity (Kwon \& Cho, 2015).

The level of anonymity that a social media platform affords its users has been recorded to positively influence its users' disinhibited engagement online (Rowe, 2015). For instance, news websites that allow its readers to post their comments without logging into an online account, which consequently increases the users' level of anonymity in the platform, has been attributed for the higher incidence of uncivil posts in news websites (Hille \& Bakker, 2014; Rowe, 2015). In contrast, news websites' Facebook pages would require users to be logged into their Facebook accounts to be able to post their comments, thus decreasing their level of anonymity in the platform (Hille \& Bakker, 2014; Rowe, 2015). Indeed, Rowe (2015) found that the higher level of anonymity that the Washington Post's website affords its participants allowed for significantly higher occurrence of incivility compared to the relatively lower level of anonymity that the Washington Post's Facebook page affords, where participants can be identified and therefore be held accountable for their posts. Moreover, Rowe (2015) also found that it is more common for uncivil comments in Washington Post's website to be directed at other discussants in the platform, compared to uncivil posts in Washington Post's Facebook page, which tend to be less interpersonal and aimed at others outside the discussion forum.

My study thus aims to compare the two social media platforms that have been documented to afford its participants different levels of anonymity and, consequently, possibilities for online disinhibited behavior. Apart from identifying the forms of incivility, plotting the timeline of occurrence of incivility, and determining the density of incivility in the reader comments section of PDI's news website and official Facebook page, my study also aims to compare the landscape of incivility between $P D I$ 's news website and official Facebook page to find out if the relatively more anonymous platform of its news website would make uncivil posts in the said platform more common. 


\section{Analyzing PDI's Reader Comments Sections}

In examining $P D I$ s reader comments environment, I conducted a content analysis of the comments posted in the reader comments section of PDI's news website and official Facebook page. Content analysis is a "messagecentered research methodology" (Neuendrof, 2002, p. 9) that "focuses on describing message characteristics [by] taking into account different possible comparison items" (Pernia, 2004, p. 34). As such, it is the best method that enabled me to identify the forms of incivility that occurred in PDI's reader comments section, the location of uncivil comments, and to whom they are directed; to plot the timeline of occurrence of the most popular forms of incivility; and to determine the density of incivility in PDI's reader comments field.

Some notable content analysis studies on incivility in interactive digital media include Papacharissi's (2004) analysis of the level of civility/incivility in 287 discussion threads in political newsgroups; Sarah Sobieraj and Jeffrey M. Berry's (2011) analysis of outrage in political blogs, talk radio, and cable news over a 10-week period; Rowe's (2015) analysis of occasions of incivility in comments posted on Washington Post's news website and on Washington Post's Facebook page; and Coe, Kenski, and Rains' (2014) analysis of the occurrence of incivility in comments posted in a local newspaper's website.

My research team analyzed the reader comments posted in the reader comments field of PDI's news website and official Facebook page. In doing so, we selected the day's top trending news article, which PDI lists under its "Trending" sidebar and operationalizes as the article with the widest number of "shares". Top trending news articles typically accumulate over a hundred comments on its trending day alone.

A total of seven top trending news articles was selected from September 2017 (representing the last month of the third quarter of 2017) to October 2017 (representing the first month of the fourth quarter of 2017). Each article represented one random day of the week over seven consecutive weeks. These articles represented one nonrepeating day in a seven-day constructed week. Constructed week sampling allows researchers to address the probable periodicity inherent in the cyclical nature of daily news reporting (Rife, Lacey, \& Fico, 1998 cited in Krippendorf, 2004; Rowe; 2013).

The trending news articles of the pertinent day of the constructed week were monitored the whole day until the 24th hour of their online publication. While PDI reports several trending news articles on its sidebar, which sometimes includes previous-day articles that continue to trend, only the trending news articles published on the pertinent day of the constructed week were included in the monitoring. The trending news article with the most number of shares after the 24th hour of its online publication 
was selected as the top trending news article of the pertinent day of the constructed week. Table 2 presents the top trending news articles selected over a seven-week period and the number of comments generated within the study's archiving timeframe.

Table 2. Top Trending News Article Over the Seven-Day Constructed Week

\begin{tabular}{|c|c|c|c|c|}
\hline Wks & $\begin{array}{l}\text { Random } \\
\text { Number }\end{array}$ & $\begin{array}{l}\text { Corresponding } \\
\text { Date }\end{array}$ & $\begin{array}{l}\text { Top Trending News Article of } \\
\text { the Day }\end{array}$ & $\begin{array}{l}\text { Number of } \\
\text { Comments }\end{array}$ \\
\hline \multirow[t]{3}{*}{$1^{\text {st }}$} & \multirow{3}{*}{$\begin{array}{l}5^{\text {th }} \text { day } \\
\text { (Thursday) }\end{array}$} & \multirow[t]{3}{*}{ September 7} & \multirow{3}{*}{$\begin{array}{l}\text { Carl Arnaiz case: Cabbie gave } 2 \\
\text { statements to police }\end{array}$} & Website: 84 \\
\hline & & & & FB: 47 \\
\hline & & & & Total: 131 \\
\hline \multirow[t]{3}{*}{$2^{\text {nd }}$} & \multirow{3}{*}{$\begin{array}{l}1^{\text {st }} \text { day } \\
\text { (Sunday) }\end{array}$} & \multirow[t]{3}{*}{ September 10} & \multirow{3}{*}{$\begin{array}{l}5 \text { nurses suspended in US for } \\
\text { admiring dead patient's genitals }\end{array}$} & Website: 35 \\
\hline & & & & FB: 97 \\
\hline & & & & Total: 132 \\
\hline \multirow[t]{3}{*}{$3^{\text {rd }}$} & \multirow{3}{*}{$\begin{array}{l}4^{\text {th }} \text { day } \\
\text { (Wednesday) }\end{array}$} & \multirow[t]{3}{*}{ September 20} & \multirow{3}{*}{$\begin{array}{l}\text { MPD: Man who found hazing } \\
\text { victim's body now'a person of } \\
\text { interest' }\end{array}$} & Website: 34 \\
\hline & & & & FB: 9 \\
\hline & & & & Total: 43 \\
\hline \multirow[t]{3}{*}{$4^{\text {th }}$} & \multirow{3}{*}{$\begin{array}{l}2^{\text {nd }} \text { day } \\
\text { (Monday) }\end{array}$} & \multirow[t]{3}{*}{ September 25} & \multirow{3}{*}{$\begin{array}{l}\text { He dies in Bulacan drug bust; she } \\
\text { turns up dead in Cagayan }\end{array}$} & Website: 181 \\
\hline & & & & FB: 195 \\
\hline & & & & Total: 376 \\
\hline \multirow[t]{3}{*}{$5^{\text {th }}$} & \multirow{3}{*}{$\begin{array}{l}3^{\text {rd day }} \\
\text { (Tuesday) }\end{array}$} & \multirow[t]{3}{*}{ October 3} & \multirow{3}{*}{$\begin{array}{l}\text { Duterte to Sereno, Morales: } \\
\text { Let's show our bank books to } \\
\text { lawmakers }\end{array}$} & Website: 895 \\
\hline & & & & FB: 598 \\
\hline & & & & Total: 1,493 \\
\hline \multirow[t]{3}{*}{$6^{\text {th }}$} & \multirow{3}{*}{$\begin{array}{l}7^{\text {th }} \text { day } \\
\text { (Saturday) }\end{array}$} & \multirow[t]{3}{*}{ October 14} & \multirow{3}{*}{$\begin{array}{l}\text { Anti-Duterte blogger comes out } \\
\text { in the open }\end{array}$} & Website: 254 \\
\hline & & & & FB: 1,240 \\
\hline & & & & Total: 1,494 \\
\hline \multirow[t]{3}{*}{$7^{\text {th }}$} & \multirow{3}{*}{$\begin{array}{l}6^{\text {th }} \text { day } \\
\text { (Friday) }\end{array}$} & \multirow[t]{3}{*}{ October 20} & \multirow{3}{*}{$\begin{array}{l}\text { Trillanes seeking US help to } \\
\text { topple } \\
\text { gov't-Cayetano }\end{array}$} & Website: 313 \\
\hline & & & & FB: 1,273 \\
\hline & & & & Total: 1,586 \\
\hline
\end{tabular}

The online comments, which were all publicly available in PDI's news website and official FB page, were collected as text for analysis. The comments were de-identified as no attempts were made to link the comments to the source given that the intent of the analysis is essentially to discover the presence of incivility in an online discourse environment. De-identifying the comments facilitated the protection of the identity of the source even if such comments were published in a public domain (franzke, Bechmann, Zimmer, Ess, \& the Association of Internet Researchers, 2020).

A total of 5,255 reader comments were gathered over the seven-day constructed week. Overall, week 7 (October 20) generated the greatest 
number of reader comments within the study's archiving timeframe $\left(N_{\text {Total }}\right.$ $=1,586)$ while week 3 (September 20) generated the least number of reader comments $\left(N_{\text {Total }}=43\right)$. In terms of website posting, week 5 (October 20) generated the most number of website reader comments within the study's archiving timeframe $\left(N_{\text {website }}=895\right)$ and week 3 (September 20) likewise generated the least $\left(N_{\text {Website }}=34\right)$. With respect to Facebook page posting, week 7 (October 20) also generated the most $\left(N_{\text {Facebook }}=1,273\right)$ and week 3 (September 20) generated the least $\left(N_{\text {Facebook }}=9\right)$.

Incivility coding was performed on all reader comments posted since the time of the online publication of the top trending news article until it was archived by the team at the end of the corresponding date. My team analyzed the presence, absence, and if present, the form/s of incivility in each and every comment posted in the reader comments field of PDI's top trending news article of the day. We used the operational definition of the forms of incivility listed in Table 3 to code the presence ("1") or absence ("0") of incivility and specified which form/s of incivility occurred, meaning multiple forms of incivility may occur in a single comment. My team also identified the location of incivility (either as main comment, first-level comment, second-level comment, or third-level comment) and the target of incivility (either interpersonal, other-directed, both, or neutral).

It must be noted, however, that lying, as a form of incivility under the deception dimension, was subsequently dropped from the coding list given the operational ambiguity of its conceptualization in the literature.

My team also plotted the timeline of occurrence of the most popular forms of incivility in the online reader comments environment by tracking the time progression of episodes of incivility in the reader comments section of PDI's news website and official Facebook page. In doing so, the time stamp of each and every comment posted in the reader comments field of $P D I$ 's top trending news article of the day was recorded. Time stamp coding was performed on all reader comments posted since the time of the top trending news article's online publication until it was archived by the team at the end of the corresponding date.

Similar to Papacharissi's (2004) incivility density computation in her landmark study, my study likewise determined the density of incivility in the online reader comments environment. We determined the density of incivility for every news article by dividing the number of comments with uncivil content with the total number of comments posted per news article within the study's archiving timeframe. Density, which is a number from "0" to " 1 ," was computed as a ratio of the total number of reader comments that contain at least one form of incivility with the total number of reader comments posted. In this study, densities were reported as percentages (i.e., 
multiplying the resulting ratio by 100). The total values that were included in the density computations only covered the reader comments posted from the time the original articles were published online until they were archived by the team at the end of their corresponding dates.

Given these, I described the general landscape of incivility in PDIs reader comments field. Moreover, inspired by Rowe's (2015) comparison of the incidences of incivility in reader comments on Washington Post's website and its official Facebook page, my study described the differences in the occurrence of incivility in PDI's news website and official Facebook page. A quick examination reveals that different sets of reader comments are posted in PDI's website and Facebook page; it would be interesting to find out if these two platforms differ with respect to incidences of incivility.

A digital content analysis coding worksheet was developed in SPSS to enable direct encoding of content analysis data. Each row in the SPSS worksheet corresponded to one reader comment while each column represented one variable. A content analysis coding guide was developed listing the variables and their corresponding codes [Table 3].

My research team was composed of four research assistants trained to conduct accurate coding. Pretesting was likewise conducted before the actual data gathering to check for inter-coder reliability. After two rounds of testing using SPSS, the final Cohen's kappa $(k)$ values ranged from 0.67 to 1.00 indicating moderate to almost perfect agreement among the coders (McHugh, 2012). Six forms of incivility fall within the moderate range, seven within the strong range, and three within the almost perfect range [Table 3].

Table 3. Coding Matrix in Accounting for the Presence and Forms of Incivility

\begin{tabular}{|l|l|l|c|}
\hline $\begin{array}{c}\text { Dimensions of } \\
\text { Incivility }\end{array}$ & \multicolumn{1}{|c|}{$\begin{array}{c}\text { Incivility } \\
\text { Variables }\end{array}$} & \multicolumn{1}{|c|}{ Measures } & Kappa $(k)$ \\
\hline Utterance Incivility & Name-calling & $\begin{array}{l}\text { For every reader comment, code "1" for } \\
\text { presence of derogatory names to express } \\
\text { distaste or contempt; code "0" if otherwise. }\end{array}$ & 0.85 \\
\hline & $\begin{array}{l}\text { Character } \\
\text { assassination }\end{array}$ & $\begin{array}{l}\text { For every reader comment, code "1" for } \\
\text { presence of an attack on the reputation or } \\
\text { integrity of someone or something; code } \\
\text { "0" if otherwise. }\end{array}$ & 0.86 \\
\hline & $\begin{array}{l}\text { Stand } \\
\text { assassination }\end{array}$ & $\begin{array}{l}\text { For every reader comment, code "1" for } \\
\text { presence of an attack on an opponent's } \\
\text { stand on issues; code "0" if otherwise. }\end{array}$ & 0.87 \\
\hline & Stereotyping & $\begin{array}{l}\text { For every reader comment, code "1" } \\
\text { for presence of labels to associate an } \\
\text { opponent with a group; code "0" if } \\
\text { otherwise. }\end{array}$ & 0.79 \\
\hline
\end{tabular}




\begin{tabular}{|c|c|c|c|}
\hline & Demonize & $\begin{array}{l}\text { For every reader comment, code " } 1 \text { " for } \\
\text { presence of statements that demonize an } \\
\text { opponent; code " } 0 \text { " if otherwise. }\end{array}$ & 0.91 \\
\hline & Mockery & $\begin{array}{l}\text { For every reader comment, code " } 1 \text { " } \\
\text { for presence of statements that jeer an } \\
\text { opponent; code "0" if otherwise. }\end{array}$ & 0.68 \\
\hline & Vulgarity & $\begin{array}{l}\text { For every reader comment, code " } 1 \text { " for } \\
\text { presence of profane or obscene language; } \\
\text { code " } 0 \text { " if otherwise. }\end{array}$ & 0.86 \\
\hline & Slur & $\begin{array}{l}\text { For every reader comment, code " } 1 \text { " for } \\
\text { presence of racial, sexist, ethnic, or religious } \\
\text { insult; code " } 0 \text { " if otherwise. }\end{array}$ & 0.75 \\
\hline & Shout & $\begin{array}{l}\text { For every reader comment, code " } 1 \text { " for } \\
\text { presence of uppercase letters or multiple } \\
\text { exclamation points; code " } 0 \text { " if otherwise. }\end{array}$ & 0.84 \\
\hline & $\begin{array}{l}\text { Pejorative } \\
\text { speech }\end{array}$ & $\begin{array}{l}\text { For every reader comment, code " } 1 \text { " for } \\
\text { presence of disparaging remarks about an } \\
\text { opponent's manner of expression; code "0" } \\
\text { if otherwise. }\end{array}$ & 1.00 \\
\hline & Aspersion & $\begin{array}{l}\text { For every reader comment, code " } 1 \text { " for } \\
\text { presence of disparaging words directed at } \\
\text { an idea, plan, policy, or behavior; code "0" } \\
\text { if otherwise. }\end{array}$ & 0.77 \\
\hline Discursive Incivility & $\begin{array}{l}\text { Threat to } \\
\text { freedom of } \\
\text { speech and } \\
\text { expression }\end{array}$ & $\begin{array}{l}\text { For every reader comment, code " } 1 \text { " for } \\
\text { presence of statements that threaten an } \\
\text { opponent's freedom to voice an opinion; } \\
\text { code " } 0 \text { " if otherwise. }\end{array}$ & 1.00 \\
\hline & $\begin{array}{l}\text { Threat to } \\
\text { person }\end{array}$ & $\begin{array}{l}\text { For every reader comment, code " } 1 \text { " for } \\
\text { presence of statements that threaten } \\
\text { an opponent with physical harm and } \\
\text { encouraging others to inflict physical harm; } \\
\text { code " } 0 \text { " if otherwise. }\end{array}$ & 0.80 \\
\hline & Refusal to listen & $\begin{array}{l}\text { For every reader comment, code " } 1 \text { " for } \\
\text { presence of statements that imply refusal } \\
\text { to listen to an opponent's viewpoints; code } \\
\text { "0" if otherwise. }\end{array}$ & 0.67 \\
\hline \multirow[t]{2}{*}{ Deception } & Hyperbole & $\begin{array}{l}\text { For every reader comment, code " } 1 \text { " for } \\
\text { presence of exaggerated statements that } \\
\text { misrepresent or obscure the truth; code " } 0 \text { " } \\
\text { if otherwise. }\end{array}$ & 0.86 \\
\hline & $\begin{array}{l}\text { Lack of } \\
\text { evidence }\end{array}$ & $\begin{array}{l}\text { For every reader comment, code " } 1 \text { " for } \\
\text { failing to provide reasons and evidence } \\
\text { to support one's opinion; code " } 0 \text { " if } \\
\text { otherwise. }\end{array}$ & 0.70 \\
\hline
\end{tabular}

Note: McHugh (2012) recommends the following interpretation of Cohen's kappa: Almost perfect $k=$ above 0.90$)$, strong $(k=0.80-0.90)$, moderate $(k=0.60-0.79)$, weak $(k=0.40-0.59)$, minimal $(k=0.21-0.39)$, none $(k=0.00-0.20)$.

While a seven-day constructed week period can adequately provide a snapshot of the landscape of incivility in two months, it is nonetheless 
recommended that further studies expand the number of days included in its constructed week sampling. Moreover, it is also recommended that future studies incorporate a longer archiving timeframe to generate a more thorough temporal description of the landscape of incivility.

\section{Incidence of Incivility in PDI's Reader Comments Environment}

\section{A. Forms of Incivility}

In general, results indicate that almost half of the coded data are classified as containing character assassination (49.1\%), making it the most popular form of incivility in $P D I$ 's reader comments section. This form of incivility is followed by stand assassination (27.9\%), mockery (25.7\%), and name-calling (24.9\%). Forms with the lowest incidence are pejorative speech $(0.6 \%)$, threat to freedom of speech and expression (0.7\%), and demonizing $(0.8 \%)$ [Table 4].

In terms of website posting, character assassination is also the most popular form of incivility (57.5\%), followed by name-calling (36.2\%), and stand assassination (35.4\%). With respect to Facebook posting, character assassination (44.9\%), stand assassination (24.1\%), and mockery (23.9\%) were the most popular.

Table 4. Occurrence of Incivility

\begin{tabular}{|c|c|c|c|c|c|c|c|}
\hline \multirow{2}{*}{ Dimension } & \multirow{2}{*}{ Forms of Incivility } & \multicolumn{2}{|c|}{$\begin{array}{c}\text { Website } \\
(N=1,759)\end{array}$} & \multicolumn{2}{|c|}{$\begin{array}{c}\text { FB } \\
(\mathrm{N}=3,496)\end{array}$} & \multicolumn{2}{|c|}{$\begin{array}{c}\text { Total } \\
(\mathrm{N}=5,255) \\
\end{array}$} \\
\hline & & f & $\%$ & f & $\%$ & f & $\%$ \\
\hline \multirow{11}{*}{ Utterance } & Name-calling & 636 & 36.2 & 671 & 19.2 & 1,307 & 24.9 \\
\hline & $\begin{array}{l}\text { Character } \\
\text { Assassination }\end{array}$ & 1,011 & 57.5 & 1,570 & 44.9 & 2,581 & 49.1 \\
\hline & $\begin{array}{l}\text { Stand } \\
\text { Assassination }\end{array}$ & 623 & 35.4 & 842 & 24.1 & 1,465 & 27.9 \\
\hline & Stereotyping & 130 & 7.4 & 140 & 4.0 & 270 & 5.1 \\
\hline & Demonize & 16 & 0.9 & 27 & 0.8 & 43 & 0.8 \\
\hline & Mockery & 513 & 29.2 & 836 & 23.9 & 1,349 & 25.7 \\
\hline & Vulgarity & 87 & 4.9 & 68 & 1.9 & 155 & 2.9 \\
\hline & Slur & 64 & 3.6 & 48 & 1.4 & 112 & 2.1 \\
\hline & Shout & 296 & 16.8 & 233 & 6.7 & 529 & 10.1 \\
\hline & Pejorative Speech & 10 & 0.6 & 22 & 0.6 & 32 & 0.6 \\
\hline & Aspersion & 283 & 16.1 & 222 & 6.4 & 505 & 9.6 \\
\hline \multirow{3}{*}{ Discursive } & $\begin{array}{l}\text { Threat to freedom } \\
\text { of speech and } \\
\text { expression }\end{array}$ & 18 & 1.0 & 19 & 0.5 & 37 & 0.7 \\
\hline & Threat to person & 60 & 3.4 & 133 & 3.8 & 193 & 3.7 \\
\hline & Refusal to listen & 9 & 0.5 & 96 & 2.7 & 105 & 2.0 \\
\hline
\end{tabular}




\begin{tabular}{|l|l|r|r|r|r|r|r|}
\hline \multirow{2}{*}{ Deception } & Hyperbole & 79 & 4.5 & 85 & 2.4 & 164 & 3.1 \\
\cline { 2 - 8 } & Lack of Evidence & 77 & 4.4 & 109 & 3.1 & 186 & 3.5 \\
\hline
\end{tabular}

Note: $N$ represents the total number of civil and uncivil reader comments posted in PDI's news website and official Facebook page within the study's archiving timeframe.

The incidence of incivility was also located per comment level, that is, whether the uncivil comment occurred in the main comment, in the firstlevel reply, in the second-level reply, or the third-level reply. However, thirdlevel replies are not possible in Facebook's comments section, thus, figures listed for this level are only for PDI website's reader comments section.

Among the 2,622 uncivil main comments, $67.1 \%$ contain character assassination, $36.7 \%$ contain stand assassination, and $32.4 \%$ contain namecalling [Table 5]. The greatest number of uncivil first-level replies contains character assassination (58.2\%), followed by mockery (37.9\%), and stand assassination (34.5\%) $\left(N_{\text {First-level }}=1,216\right)$. For uncivil second-level replies, $55.6 \%$ contain character assassination, $46.0 \%$ contain stand assassination, $44.4 \%$ contain mockery, and the same percentage (44.4\%) contains aspersion $\left(N_{\text {Second-level }}=126\right)$. Meanwhile, among the uncivil third-level replies, $72.9 \%$ contain character assassination, $67.8 \%$ contain mockery, and $52.5 \%$ contain name-calling $\left(N_{\text {Third-level }}=77\right)$. This shows that first-, second-, and third-level replies generally mimic the popular forms of incivility present in the main comment section.

With respect to particular reader comments environment, character assassination is the most popular form of incivility in both the website's main and first-level comments (main comment $=74.2 \%$; first-level $=69.3 \%$ ) and Facebook's main and first-level comments (main comment $=63.5 \%$; firstlevel $=53.7 \%$ ). As for the second-level comments, character assassination remains the most recurring in website posting (56.9\%) while mockery has the highest incidence in Facebook posting (58.3\%). Character assassination (72.9\%) is also the most popular form of incivility in third-level comments.

The target of uncivil comments, which can be interpersonal, otherdirected, both, or neutral, was also observed and recorded. Results show that most of the uncivil comments were directed toward a person or entity outside the comments section $\left(N_{\text {Other-directed }}=3,165\right)$. Usually, these persons or entities are the topic of the article or are related to it. Results also show that character assassination is also the most popular form of incivility across all targets [Table 6]. 


\begin{tabular}{|c|c|c|c|c|c|c|c|c|c|c|c|c|c|c|c|c|c|c|c|}
\hline \multirow{6}{*}{ 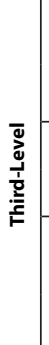 } & \multirow{2}{*}{ 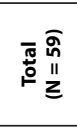 } & $\therefore$ & ָิ & $\stackrel{\stackrel{i}{ }}{ }$ & $\bar{f}$ & 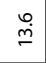 & 0 & $\stackrel{\infty}{\hat{\sigma}}$ & 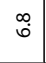 & $\stackrel{9}{=}$ & 节 & $\stackrel{\infty}{\emptyset}$ & 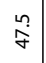 & $\cong$ & 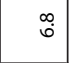 & $\stackrel{\vec{m}}{\mathrm{~m}}$ & $\stackrel{m}{\stackrel{m}{n}}$ & $\stackrel{+}{m}$ & \multirow{2}{*}{ 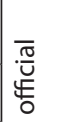 } \\
\hline & & - & $\bar{m}$ & $\mathscr{q}$ & $\stackrel{\sim}{\sim}$ & $\infty$ & 0 & q & $\sigma$ & $\wedge$ & $\stackrel{n}{n}$ & $\sigma$ & $\stackrel{\infty}{\sim}$ & - & $\sigma$ & $\sim$ & $a$ & $\sim$ & \\
\hline & \multirow{2}{*}{ 总 } & $\therefore$ & 1 & 1 & 1 & 1 & 1 & 1 & 1 & 1 & 1 & 1 & 1 & 1 & 1 & 1 & 1 & 1 & $\frac{\bar{T}}{\sigma}$ \\
\hline & & 4 & : & : & 1 & i & : & 1 & : & : & : & : & : & : & : & : & : & : & $\frac{\stackrel{ \pm}{n}}{\omega}$ \\
\hline & \multirow{2}{*}{ 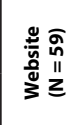 } & $\therefore$ & 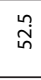 & $\stackrel{\vec{i}}{ }$ & $\bar{f}$ & $\begin{array}{l}\stackrel{o}{m} \\
\stackrel{m}{~}\end{array}$ & 0 & $\stackrel{\infty}{\overleftarrow{b}}$ & $\stackrel{\infty}{\infty}$ & $\stackrel{\stackrel{g}{=}}{=}$ & 节 & 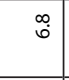 & $\begin{array}{l}\stackrel{n}{\sigma} \\
\tilde{f}\end{array}$ & $\cong$ & $\begin{array}{l}\infty \\
\dot{0}\end{array}$ & $\stackrel{\grave{m}}{\mathrm{~m}}$ & $\stackrel{m}{n}$ & $\stackrel{\vec{m}}{\vec{m}}$ & $\begin{array}{l}0 \\
3 \\
3 \\
n \\
3\end{array}$ \\
\hline & & + & $\bar{m}$ & $\mathscr{q}$ & $\stackrel{\sim}{\sim}$ & $\infty$ & 0 & q & $\sigma$ & $n$ & $\stackrel{n}{\simeq}$ & $\sigma$ & $\stackrel{\infty}{\sim}$ & - & $\sigma$ & $\sim$ & $a$ & $\sim$ & $\underset{\sim}{\bar{v}}$ \\
\hline \multirow{6}{*}{ 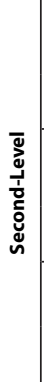 } & \multirow{2}{*}{ 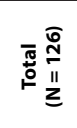 } & $\therefore$ & $\hat{\tilde{m}}$ & $\begin{array}{l}\circ \\
\stackrel{\leftrightarrow}{n}\end{array}$ & $\begin{array}{l}\stackrel{\circ}{\sigma} \\
\end{array}$ & $\check{r}$ & $\stackrel{\circ}{-}$ & $\underset{j}{\dot{J}}$ & $\stackrel{\infty}{0}$ & $\bar{\curvearrowright}$ & $\stackrel{m}{\infty}$ & $\stackrel{\sim}{m}$ & $\underset{j}{J}$ & $\stackrel{\infty}{\circ}$ & $\stackrel{\infty}{+}$ & $\stackrel{\circ}{-}$ & $\stackrel{\circ}{\circ}$ & $\stackrel{\overbrace{}}{\sim}$ & $\begin{array}{l}0 \\
a \\
.\end{array}$ \\
\hline & & + & in & 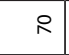 & $\stackrel{\infty}{n}$ & $a$ & $\sim$ & i & - & $\sigma$ & $\ddot{\sim}$ & $\nabla$ & $\stackrel{\circ}{n}$ & - & 0 & $\sim$ & n & $m$ & $\stackrel{0}{\tilde{n}}$ \\
\hline & \multirow{2}{*}{ 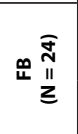 } & $\therefore$ & $\stackrel{m}{m}$ & $\stackrel{0}{\circ}$ & $\begin{array}{l}\stackrel{\dot{\omega}}{\mathrm{j}} \\
\text {. }\end{array}$ & 0 & $\circ$ & $\stackrel{m}{\infty}$ & 0 & $\stackrel{\sim}{\sim}$ & $\underset{\infty}{m}$ & 0 & $\hat{\circ}$ & 0 & $\stackrel{\stackrel{\sim}{\beth}}{=}$ & $\stackrel{\sim}{\sim}$ & 0 & $\underset{\sim}{\sim}$ & $\frac{0}{\stackrel{0}{c}}$ \\
\hline & & - & $\infty$ & $\simeq$ & 6 & 0 & 0 & \pm & 0 & - & $N$ & 0 & $\sigma$ & 0 & $m$ & - & 0 & - & દ્ \\
\hline & \multirow{2}{*}{ 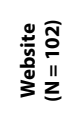 } & $\therefore$ & $\stackrel{\sim}{F}$ & $\begin{array}{l}\stackrel{a}{0} \\
\stackrel{\circ}{n}\end{array}$ & $\frac{0}{i n}$ & $\begin{array}{l}\infty \\
\infty \\
\infty\end{array}$ & $\stackrel{\stackrel{i}{i}}{ }$ & 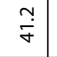 & $\stackrel{\circ}{-}$ & $\stackrel{\infty}{\wedge}$ & ¿̊․ & $\stackrel{\vec{m}}{\vec{m}}$ & $\stackrel{\circ}{i}$ & $\stackrel{\circ}{-}$ & $\stackrel{\overrightarrow{\mathrm{N}}}{ }$ & $\stackrel{\circ}{-}$ & 잉 & $\stackrel{\circ}{\text { i }}$ & $\frac{1}{0}$ \\
\hline & & - & $\mathcal{F}$ & $\infty$ & ก & $a$ & $N$ & $\mathcal{F}$ & - & $\infty$ & $\bar{N}$ & $\sigma$ & in & - & $m$ & - & n & $\sim$ & 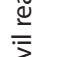 \\
\hline \multirow{6}{*}{ 离 } & \multirow{2}{*}{ 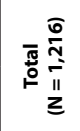 } & $\therefore$ & $\stackrel{\circ}{\dot{m}}$ & $\stackrel{\substack{\infty \\
\infty}}{\stackrel{\infty}{\infty}}$ & 吕 & $\stackrel{\circ}{i}$ & $\stackrel{\simeq}{=}$ & $\stackrel{a}{\hat{m}}$ & $\stackrel{\infty}{+}$ & $\stackrel{\circ}{\dot{m}}$ & $\hat{\Xi}$ & $\stackrel{\circ}{-}$ & $\begin{array}{c}\infty \\
\stackrel{\infty}{\sim}\end{array}$ & $\stackrel{\circ}{-}$ & $\hat{f}$ & $\stackrel{+}{+}$ & $\stackrel{+}{+}$ & $\stackrel{+}{+}$ & $\underset{\breve{J}}{\breve{y}}$ \\
\hline & & - & 命 & $\stackrel{\infty}{\curvearrowright}$ & $\stackrel{\curvearrowright}{\mathscr{q}}$ & $\stackrel{\llcorner}{\infty}$ & \pm & $\bar{f}$ & $\stackrel{\infty}{\stackrel{\infty}{n}}$ & $\stackrel{m}{\circ}$ & $\stackrel{\text { 号 }}{\curvearrowleft}$ & $\stackrel{\text { i }}{\text { s. }}$ & 品 & $\simeq$ & in & n̂ & 亡n & in & $\begin{array}{l}\bar{\varpi} \\
\stackrel{\bar{\nu}}{\varepsilon}\end{array}$ \\
\hline & \multirow{2}{*}{ 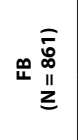 } & $\therefore$ & 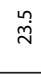 & î̀ & $\stackrel{m}{\stackrel{m}{m}}$ & $\stackrel{\circ}{\circ}$ & $\stackrel{m}{=}$ & $\begin{array}{l}\stackrel{0}{m} \\
m\end{array}$ & $\stackrel{\infty}{\sim}$ & $\stackrel{g}{-}$ & $\stackrel{\nabla}{0}$ & $\tilde{N}$ & $\underset{\sim}{\sim}$ & $\stackrel{\infty}{\circ}$ & นี & $\hat{n}$ & $\stackrel{\infty}{+}$ & $\stackrel{\sim}{\sim}$ & $\frac{\vec{D}}{\frac{D}{\pi}}$ \\
\hline & & - & న్ & $\tilde{f}$ & $\bar{\sim}$ & ก & $=$ & $\stackrel{\infty}{\sim}$ & 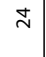 & $\bullet$ & in & $\stackrel{\sigma}{ }$ & $\tilde{\sigma}$ & $\wedge$ & ฯ & $g$ & $\bar{\sigma}$ & ले & 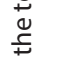 \\
\hline & \multirow{2}{*}{ 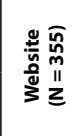 } & $\therefore$ & $\stackrel{m}{g}$ & $\frac{m}{0}$ & $\begin{array}{l}\infty \\
\dot{f}\end{array}$ & $\stackrel{m}{a}$ & $\stackrel{\infty}{\circ}$ & $\begin{array}{l}n \\
\substack{\alpha \\
\sigma}\end{array}$ & $\stackrel{\circ}{\circ}$ & $\begin{array}{l}\stackrel{0}{i n} \\
\stackrel{n}{n}\end{array}$ & 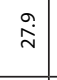 & m. & $\mathfrak{f}$ & $\stackrel{\square}{\leftrightarrows}$ & $\stackrel{+}{m}$ & $\mp$ & $\hat{m}$ & $\stackrel{\sim}{\mp}$ & 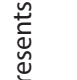 \\
\hline & & - & 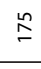 & $\stackrel{\mathbb{S}}{\sim}$ & 乌ิ & $\stackrel{m}{m}$ & $m$ & $\stackrel{N}{ \pm}$ & $\stackrel{m}{m}$ & 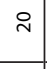 & ร & - & $\stackrel{\infty}{\stackrel{\circ}{n}}$ & in & $\simeq$ & $\sigma$ & $\underline{m}$ & $\stackrel{\llcorner}{\llcorner}$ & $\frac{\overline{0}}{\frac{0}{2}}$ \\
\hline \multirow{6}{*}{ 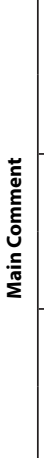 } & \multirow{2}{*}{ 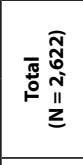 } & $\therefore$ & $\underset{m}{\stackrel{\sim}{~}}$ & $\overline{\dot{\theta}}$ & 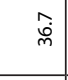 & ఫ̊ర & $\stackrel{\circ}{-}$ & 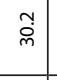 & $\stackrel{n}{m}$ & $\stackrel{m}{\sim}$ & 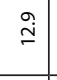 & $\tilde{o}$ & $\grave{i}$ & $\stackrel{n}{0}$ & $\stackrel{\infty}{+}$ & $\stackrel{\infty}{-}$ & $\stackrel{\circ}{\dot{m}}$ & $\stackrel{\infty}{\sim}$ & 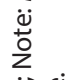 \\
\hline & & - & $\underset{\infty}{\stackrel{\Im}{2}}$ & $\begin{array}{l}\stackrel{0}{\cong} \\
.\end{array}$ & $\bar{\S}$ & $\stackrel{\infty}{\circ}$ & $\grave{\sim}$ & $\widetilde{\Omega}$ & $\alpha$ & 8 & $\hat{m}$ & $\sigma$ & $\Sigma$ & $\stackrel{m}{=}$ & $\stackrel{\stackrel{\Perp}{\simeq}}{ }$ & $\stackrel{\infty}{+}$ & ठే & 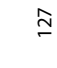 & 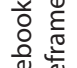 \\
\hline & \multirow{2}{*}{ 赵 } & $\therefore$ & $\stackrel{\widehat{o}}{\mathrm{~N}}$ & $\begin{array}{l}n \\
\tilde{0} \\
\tilde{6}\end{array}$ & $\stackrel{m}{m}$ & $\overline{i n}$ & ò & 户े & $\stackrel{\mathscr{N}}{\sim}$ & $\stackrel{\infty}{-}$ & $\stackrel{\simeq}{\circ}$ & ฮ̃ & $\stackrel{n}{\longrightarrow}$ & $\hat{o}$ & $\stackrel{q}{+}$ & $\hat{i}$ & $\stackrel{n}{\mathrm{~N}}$ & $\stackrel{\circ}{+}$ & 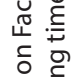 \\
\hline & & - & $\bar{g}$ & $\stackrel{\circ}{\circ}$ & in & $\infty$ & 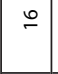 & & $\neq$ & $\bar{m}$ & 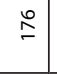 & $m$ & $\stackrel{N}{2}$ & $\simeq$ & $\infty$ & f & $\neq$ & 응 & 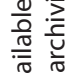 \\
\hline & \multirow{2}{*}{ 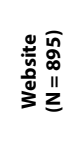 } & $\therefore$ & $\stackrel{+}{\mathscr{\gamma}}$ & $\stackrel{\text { F }}{\underset{N}{N}}$ & $\overline{\dot{q}}$ & $\begin{array}{l}\stackrel{a}{\infty} \\
\infty\end{array}$ & $\stackrel{\simeq}{=}$ & $\begin{array}{l}\stackrel{a}{\infty} \\
\stackrel{\infty}{N}\end{array}$ & i் & $\stackrel{\sim}{m}$ & $\stackrel{\circ}{\infty}$ & ó & $\stackrel{\circ}{i}$ & $\overline{0}$ & $\stackrel{\circ}{+}$ & $\tilde{o}$ & $\stackrel{\circ}{\circ}$ & นึ & $\begin{array}{l}\overrightarrow{0} \\
\stackrel{0}{0} \\
\stackrel{0}{\complement}\end{array}$ \\
\hline & & - & $\stackrel{\infty}{\infty}$ & 㕝 & $\stackrel{\infty}{\infty}$ & $\infty$ & $=$ & 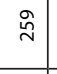 & $\stackrel{\infty}{\sigma}$ & $\stackrel{\mathbf{N}}{ }$ & $\Phi$ & - & ๖ & - & $\bar{\gamma}$ & $\sim$ & in & $\stackrel{\infty}{\circ}$ & 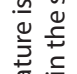 \\
\hline \multicolumn{3}{|c|}{ 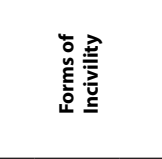 } & 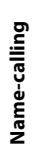 & 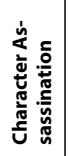 & 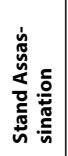 & 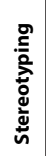 & 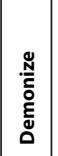 & 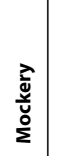 & 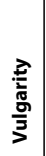 & $\frac{\grave{n}}{\bar{n}}$ & 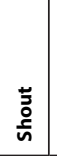 & 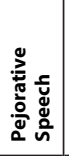 & 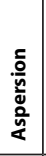 & 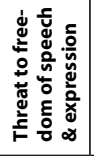 & 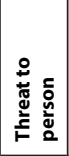 & 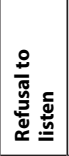 & $\begin{array}{l}\frac{0}{0} \\
\frac{0}{\overline{0}} \\
\grave{2}\end{array}$ & 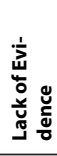 & 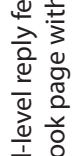 \\
\hline \multicolumn{3}{|c|}{ Dimension } & \multicolumn{11}{|c|}{ Utterance } & \multicolumn{3}{|c|}{ Discursive } & \multicolumn{2}{|c|}{ Deception } & \\
\hline
\end{tabular}




\begin{tabular}{|c|c|c|c|c|c|c|c|c|c|c|c|c|c|c|c|c|c|c|c|}
\hline \multirow{6}{*}{ 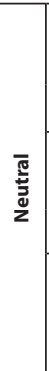 } & \multirow{2}{*}{ 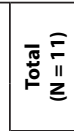 } & $\therefore$ & 0 & $\stackrel{\sim}{\infty}$ & $\stackrel{m}{\sim}$ & 0 & $\circ$ & $\bar{\sigma}$ & 0 & 0 & $\stackrel{\infty}{\infty}$ & 0 & 0 & 0 & $\bar{\sigma}$ & $\circ$ & $\bar{\sigma}$ & 它 & نُ \\
\hline & & 4 & 0 & $N$ & $m$ & 0 & 0 & - & 0 & 0 & $\sim$ & 0 & 0 & 0 & - & 0 & - & & $\frac{\pi}{2}$ \\
\hline & क $\bar{m}$ & $\therefore$ & $\circ$ & $\underset{m}{m}$ & $\circ$ & 0 & $\circ$ & $\underset{m}{m}$ & 0 & $\circ$ & 0 & 0 & 0 & $\circ$ & 0 & $\circ$ & 0 & $\underset{m}{m}$ & 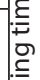 \\
\hline & & - & 0 & - & $\circ$ & 0 & 0 & - & 0 & 0 & 0 & 0 & 0 & $\circ$ & $\circ$ & 0 & 0 & - & \\
\hline & 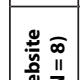 & $\therefore$ & 0 & 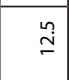 & $\stackrel{n}{\stackrel{n}{m}}$ & 0 & 0 & 0 & $\circ$ & 0 & 完 & 0 & 0 & $\circ$ & $\stackrel{\sim}{\underline{\sim}}$ & $\circ$ & $\stackrel{n}{\underline{I}}$ & $\stackrel{n}{\stackrel{n}{m}}$ & 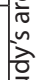 \\
\hline & & - & 0 & - & $m$ & 0 & $\circ$ & 0 & $\circ$ & 0 & $\sim$ & 0 & 0 & 0 & - & 0 & - & $m$ & \\
\hline \multirow{6}{*}{ 吾 } & \multirow{2}{*}{ 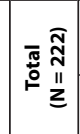 } & $\therefore$ & $\stackrel{n}{\tilde{\sigma}}$ & 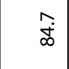 & 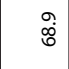 & 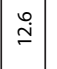 & $\stackrel{\text { ำ }}{0}$ & $\stackrel{N}{i n}$ & i் & $\stackrel{\sim}{m}$ & $\overline{\dot{m}}$ & ğ & 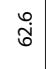 & $\stackrel{\infty}{-}$ & $\stackrel{\infty}{-}$ & $\stackrel{ \pm}{\rightleftarrows}$ & $\tilde{m}$ & & 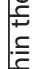 \\
\hline & & 4 & $\Phi$ & $\stackrel{\infty}{\stackrel{\infty}{\infty}}$ & $\stackrel{n}{n}$ & $\stackrel{\infty}{\sim}$ & - & $\grave{\cong}$ & $=$ & n & 8 & $N$ & $\stackrel{\tilde{m}}{\sim}$ & $\sigma$ & $\sigma$ & m & \pm & $\sim$ & 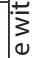 \\
\hline & ๓๓ & $\therefore$ & $\stackrel{\infty}{\stackrel{m}{m}}$ & $\stackrel{m}{n}$ & $\begin{array}{l}\stackrel{\infty}{\stackrel{\sigma}{\sigma}} \\
\end{array}$ & $\stackrel{\circ}{\infty}$ & 0 & $\hat{\mathrm{m}}$ & i̊ & $\circ$ & $\Xi$ & $\tilde{\sim}$ & 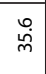 & $\tilde{N}$ & $\stackrel{m}{m}$ & $\stackrel{m}{m}$ & $\stackrel{\circ}{\infty}$ & $\tilde{\sim}$ & 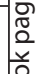 \\
\hline & & 4 & $\stackrel{\dot{m}}{\mathrm{~m}}$ & $\bullet$ & q & $\infty$ & 0 & $m$ & in & $\circ$ & $\circ$ & $\sim$ & $\approx$ & $\sim$ & $m$ & $m$ & $\infty$ & $\sim$ & \\
\hline & 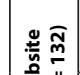 & $\therefore$ & $\overline{\bar{\infty}}$ & $\stackrel{\star}{\sim}$ & $\underset{\infty}{m}$ & 点 & $\stackrel{\infty}{0}$ & $\stackrel{\sim}{\gtrless}$ & $\stackrel{\wp}{+}$ & $\stackrel{m}{n}$ & f & $\circ$ & $\overline{\dot{\infty}}$ & $\stackrel{n}{\sim}$ & $\stackrel{\infty}{\infty}$ & $\circ$ & $\stackrel{\text { q }}{q}$ & 0 & 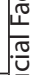 \\
\hline & šn $_{z}$ & 4 & $\stackrel{\circ}{\circ}$ & $\underset{\simeq}{ }$ & $\stackrel{ }{\underline{1}}$ & ণ & - & ष & 0 & $\wedge$ & in & $\circ$ & $\stackrel{\circ}{\circ}$ & $\sim$ & - & $\circ$ & 0 & & 告 \\
\hline \multirow{6}{*}{ 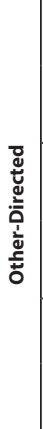 } & \multirow{2}{*}{ 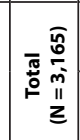 } & $\therefore$ & $\frac{\infty}{\dot{m}}$ & $\begin{array}{l}0 \\
\stackrel{0}{0}\end{array}$ & $\hat{⿱ ⺊ m}$ & $\hat{\sigma}$ & $\stackrel{\simeq}{\simeq}$ & $\hat{\dot{m}}$ & $\stackrel{\circ}{+}$ & $\stackrel{\infty}{i}$ & $\stackrel{\sim}{\simeq}$ & テ̃ & นี & oे & $\stackrel{\infty}{\stackrel{\leftarrow}{+}}$ & 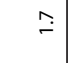 & $\stackrel{\circ}{+}$ & $\stackrel{m}{n}$ & \\
\hline & & 4 & $\stackrel{\text { ڤ̆ }}{\circ}$ & $\stackrel{\infty}{\stackrel{\infty}{\sim}}$ & 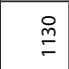 & $\overline{\bar{v}}$ & $\stackrel{\infty}{m}$ & $\Sigma$ & $\stackrel{\infty}{\sim}$ & $\begin{array}{l}\infty \\
\infty\end{array}$ & $\hat{\text { ⿵े }}$ & 0 & $\stackrel{\circ}{\circ}$ & $\hat{N}$ & 도 & in & $\stackrel{\infty}{\sim}$ & $\stackrel{0}{6}$ & 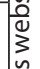 \\
\hline & 商 & $\therefore$ & $\overline{\dot{n}}$ & ֻِ & $\stackrel{\infty}{\underset{m}{m}}$ & ir & $\stackrel{\sim}{\sim}$ & $\overline{\dot{m}}$ & $\stackrel{\circ}{i}$ & $\stackrel{9}{-}$ & テุ & $\tilde{o}$ & $\stackrel{+}{m}$ & $\hat{o}$ & $\overline{\text { in }}$ & $\stackrel{\circ}{i}$ & ָु & $\dot{f}$ & 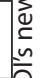 \\
\hline & & - & $\stackrel{\sim}{\sim}$ & $\stackrel{\circ}{\underline{m}}$ & 冏 & $\cong$ & $\stackrel{\sim}{\sim}$ & ஜ్రి & 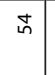 & q & $\stackrel{m}{g}$ & $\sigma$ & $\pi$ & $\stackrel{n}{2}$ & $\stackrel{8}{\circ}$ & 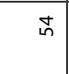 & $\infty$ & & 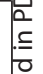 \\
\hline & 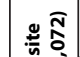 & $\therefore$ & 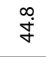 & 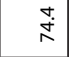 & $\stackrel{m}{q}$ & สุ & $\stackrel{\sim}{\sim}$ & $\stackrel{\infty}{\stackrel{\infty}{m}}$ & ํ. & $\stackrel{n}{q}$ & $\stackrel{\circ}{\circ}$ & $\tilde{o}$ & $\stackrel{\circ}{\infty}$ & $\mp$ & ร & $\overline{0}$ & i̊ & $\stackrel{\circ}{\circ}$ & \\
\hline & $3_{3}^{0} \pi$ & 4 & $\stackrel{\infty}{\sigma}$ & $\stackrel{\infty}{\circ}$ & $\stackrel{q}{q}$ & g & $\stackrel{m}{\underline{n}}$ & $\underset{m}{\bar{f}}$ & I & $\stackrel{\infty}{f}$ & 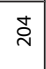 & $\sim$ & ณ & $\simeq$ & \& & - & 8 & $\pi$ & \\
\hline \multirow{6}{*}{ 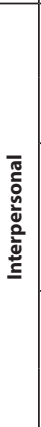 } & \multirow{2}{*}{ 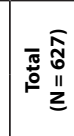 } & $\therefore$ & ڤે & 过 & $\stackrel{\substack{\infty \\
\sim}}{N}$ & $\stackrel{\leftrightarrow}{\dot{\sigma}}$ & $\stackrel{\circ}{\circ}$ & $\stackrel{\circ}{\circ}$ & $\stackrel{\circ}{i}$ & $\hat{i}$ & ò & $\stackrel{\infty}{m}$ & $\frac{a}{m}$ & $\stackrel{\circ}{-}$ & के & $\stackrel{n}{n}$ & $\stackrel{\circ}{+}$ & $\stackrel{\circ}{-}$ & 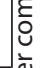 \\
\hline & & - & 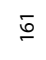 & $\stackrel{\infty}{N}$ & $\stackrel{\vartheta}{\check{2}}$ & $\bar{m}$ & $\sigma$ & $\stackrel{\infty}{\sim}$ & $\stackrel{0}{\circ}$ & $=$ & $\overline{6}$ & $\stackrel{\text { N }}{ }$ & 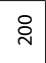 & 0 & $\hat{m}$ & f & $\stackrel{\sim}{\sim}$ & $\circ$ & 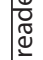 \\
\hline & \multirow{2}{*}{ 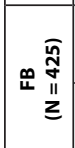 } & $\therefore$ & ఫ্ & ชุ & 总 & F & ?n & 字 & $\bar{i}$ & $\stackrel{9}{-}$ & $\check{\pi}$ & $\stackrel{\infty}{m}$ & $\stackrel{\circ}{\infty} \underset{\sim}{\infty}$ & $\tilde{n}$ & $\stackrel{0}{\circ}$ & สั & $\bar{N}$ & $\stackrel{\circ}{\longrightarrow}$ & ביב \\
\hline & & 4 & $\cong$ & $\check{\Omega}$ & $\cong$ & 尺 & $N$ & $\Sigma$ & $a$ & $\infty$ & i & $\stackrel{\circ}{\circ}$ & $\stackrel{g}{\rightleftharpoons}$ & $\sim$ & $\stackrel{\text { I }}{ }$ & m & $a$ & $n$ & to \\
\hline & \multirow{2}{*}{ 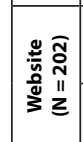 } & $\therefore$ & $\stackrel{m}{\sim}$ & $\stackrel{0}{\dot{f}}$ & $\stackrel{\sim}{m}$ & $\begin{array}{l}\dot{H} \\
\dot{\omega}\end{array}$ & $\stackrel{\circ}{-}$ & $\overline{m^{\infty}}$ & $\stackrel{n}{m}$ & $\stackrel{n}{q}$ & $\stackrel{m}{n}$ & $\stackrel{P}{+}$ & $\overline{\dot{q}}$ & $\stackrel{\leftrightarrow}{i}$ & ţ & $\stackrel{\circ}{+}$ & के & $\stackrel{n}{\longrightarrow}$ & $\underline{\underline{z}}$ \\
\hline & & 4 & g & 8 & $\widehat{6}$ & $=$ & $\sim$ & $\therefore$ & $n$ & $a$ & $\bar{m}$ & $\infty$ & $\bar{\infty}$ & $\nabla$ & $\underline{m}$ & $\infty$ & $\simeq$ & $m$ & 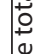 \\
\hline \multicolumn{3}{|c|}{ 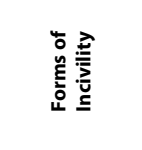 } & 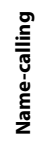 & 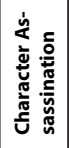 & 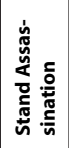 & 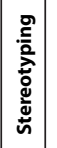 & 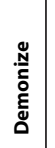 & 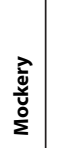 & $\begin{array}{l}\frac{2}{2} \\
\frac{2}{5} \\
\frac{5}{3}\end{array}$ & $\frac{3}{n}$ & $\begin{array}{l}\text { 䓂 } \\
\text { जu }\end{array}$ & 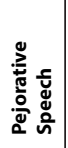 & 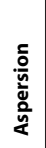 & 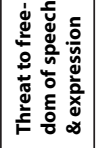 & 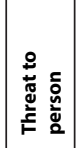 & 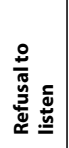 & 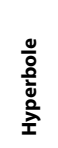 & 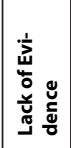 & 这 \\
\hline \multicolumn{3}{|c|}{ Dimension } & \multicolumn{11}{|c|}{ Utterance } & \multicolumn{3}{|c|}{ ursive } & \multicolumn{2}{|r|}{ otion } & \\
\hline
\end{tabular}


Among uncivil interpersonal comments, $45.0 \%$ contain character assassination, $39.6 \%$ contain mockery, and $31.9 \%$ contain aspersion $\left(N_{\text {Interpersonal }}=627\right)$. For other-directed comments that contain incivility, it has been observed that character assassination is still the most common form with $66.6 \%$ of comments containing such, followed by stand assassination (35.7\%), and name-calling (32.0\%) $\left(N_{\text {Other-directed }}=3,165\right)$. Meanwhile, uncivil comments directed at both interpersonal and others in the comment section mostly contains character assassination (84.7\%), stand assassination (68.9\%), and name-calling $(63.5 \%)\left(N_{\text {Both }}=222\right)$. Lastly, among the neutrally-targeted uncivil comments, $36.4 \%$ are classified as lacking in evidence and $27.3 \%$ contain stand assassination $\left(N_{\text {Neutral }}=11\right)$. Thus, character assassination is generally the most common form of incivility across the three targets.

For interpersonal comments, the greatest number of uncivil comments posted on the website (44.6\%) and Facebook page (45.2\%) contains character assassination. For other-directed comments, a big majority of uncivil comments posted on the website (74.4\%) and Facebook page (62.6\%) contains character assassination. For comments directed at both interpersonal and others in the comment section, almost all uncivil comments posted on the website (92.4\%) and a big majority of uncivil comments posted on Facebook (73.3\%) contain character assassination. Meanwhile, the greatest number of uncivil comments that are neutrally targeted in the website (37.5\%) and Facebook page (33.3\%) lacks evidence.

\section{B. Timeline of Occurrence of the Most Popular Forms of Incivility}

As mentioned, the overall four most popular forms of incivility are character assassination (49.1\%), stand assassination (27.9\%), mockery (25.7\%), and name-calling (24.9\%). The timeline of occurrence of these forms of incivility is plotted in Figure 1.

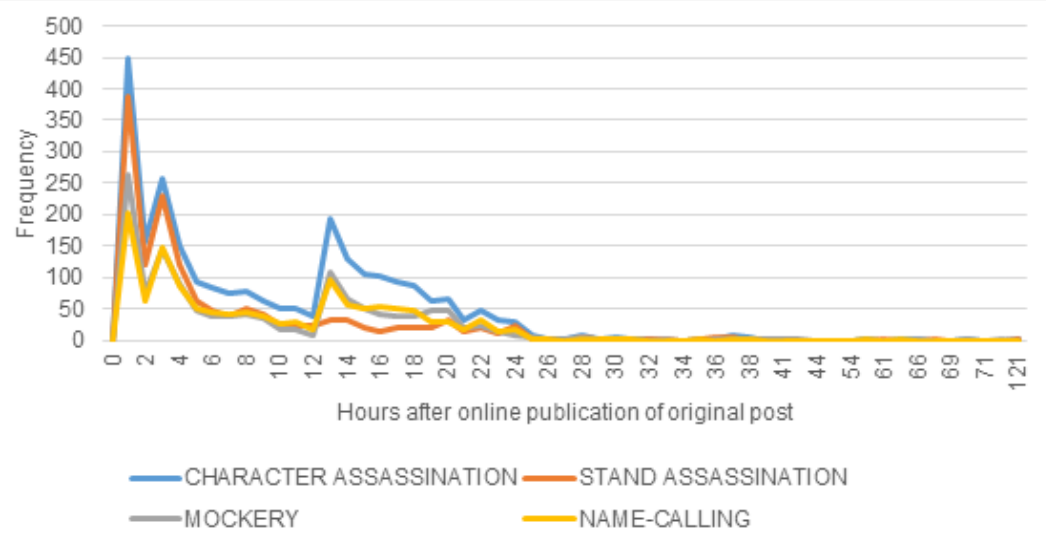

Figure 1. Occurence of the Top 4 Forms of Incivility 
Based on the graph, the four most popular forms of incivility occurred most frequently during the first four hours after posting, reaching their peak twice within that period. Additionally, it once again reaches a peak around the $13^{\text {th }}$ hour.

The highest incidence observed can be seen at the first hour, while the second peak is at the third hour. On its fourth hour until the 12th, the incidence of incivility was found to be less frequent. However, it once again spiked around the 13th hour. It can be observed that incivility is generally more present within 14 hours of the articles' online posting, after which the incidence of these forms of incivility tends to be less frequent.

\section{Density of Incivility}

Based on the articles reviewed, PDI's reader comments environment is generally uncivil and statistical tests show that there is generally higher density of incivility in PDI's website (80.2\%) compared to its official Facebook page $(74.7 \%), t(5,253)=4.450, p=0.00$. Hence, comments on PDIs website reader comments section are generally more uncivil than comments on its Facebook reader comments field [Table 7].

From the articles included in the study, results show that the top three articles with the highest density of incivility in PDI's website are "MPD: Man who found hazing victim's body now 'a person of interest"' (91.2\%); “Trillanes seeking US help to topple gov't —Cayetano" (90.1\%); and "Carl Arnaiz case: Cabbie gave 2 statements to police" (89.4\%). On the other hand, the articles with the highest density of incivility in PDIs Facebook page are "Trillanes seeking US help to topple gov't -Cayetano" (83.9\%); "Carl Arnaiz case: Cabbie gave 2 statements to police" (82.1\%); and "He dies in Bulacan drug bust; she turns up dead in Cagayan" (79.0\%). Overall, results indicate that the articles "Trillanes seeking US help to topple gov't -Cayetano" (85.1\%); "Carl Arnaiz case: Cabbie gave 2 statements to police" (84.7\%); and "MPD: Man who found hazing victim's body now 'a person of interest"' (83.7\%) have the highest density of incivility among all the articles reviewed.

Table 7. Density of Incivility

\begin{tabular}{|l|r|r|r|}
\hline News Articles & \multicolumn{1}{|c|}{$\begin{array}{c}\text { Presence of } \\
\text { Incivility in } \\
\text { Website }\end{array}$} & $\begin{array}{c}\text { Presence of } \\
\text { Incivility in FB }\end{array}$ & $\begin{array}{c}\text { Overall Presence } \\
\text { of Incivility }\end{array}$ \\
\hline Carl Arnaiz case: Cabbie gave 2 & $\begin{array}{r}89.4 \% \\
\text { statements to police }\end{array}$ & $\begin{array}{r}82.1 \% \\
(\mathrm{~N}=84)\end{array}$ & $\begin{array}{r}84.7 \% \\
(\mathrm{~N}=131)\end{array}$ \\
\hline $\begin{array}{l}5 \text { nurses suspended in US for admiring } \\
\text { dead patient's genitals }\end{array}$ & $\begin{array}{r}80.0 \% \\
(\mathrm{~N}=35)\end{array}$ & $\begin{array}{r}53.6 \% \\
(\mathrm{~N}=97)\end{array}$ & $\begin{array}{r}60.6 \% \\
(\mathrm{~N}=132)\end{array}$ \\
\hline
\end{tabular}




\begin{tabular}{|l|r|r|r|}
\hline $\begin{array}{l}\text { MPD: Man who found hazing victim's } \\
\text { body now'a person of interest' }\end{array}$ & $\begin{array}{r}91.2 \% \\
(\mathrm{~N}=34)\end{array}$ & $\begin{array}{r}55.6 \% \\
(\mathrm{~N}=9)\end{array}$ & $\begin{array}{r}83.7 \% \\
(\mathrm{~N}=43)\end{array}$ \\
\hline $\begin{array}{l}\text { He dies in Bulacan drug bust; she turns } \\
\text { up dead in Cagayan }\end{array}$ & $\begin{array}{r}79.0 \% \\
(\mathrm{~N}=181)\end{array}$ & $\begin{array}{r}79.0 \% \\
(\mathrm{~N}=195)\end{array}$ & $\begin{array}{r}79.0 \% \\
(\mathrm{~N}=376)\end{array}$ \\
\hline $\begin{array}{l}\text { Duterte to Sereno, Morales: Let's show } \\
\text { our bank books to lawmakers }\end{array}$ & $\begin{array}{r}80.8 \% \\
(\mathrm{~N}=895)\end{array}$ & $\begin{array}{r}69.2 \% \\
(\mathrm{~N}=598)\end{array}$ & $\begin{array}{r}76.2 \% \\
(\mathrm{~N}=1,493)\end{array}$ \\
\hline $\begin{array}{l}\text { Anti-Duterte blogger comes out in the } \\
\text { open }\end{array}$ & $\begin{array}{r}63.8 \% \\
(\mathrm{~N}=254)\end{array}$ & $\begin{array}{r}68.5 \% \\
(\mathrm{~N}=1,240)\end{array}$ & $\begin{array}{r}67.7 \% \\
(\mathrm{~N}=1,494)\end{array}$ \\
\hline $\begin{array}{l}\text { Trillanes seeking US help to topple } \\
\text { gov't-Cayetano }\end{array}$ & $90.1 \%$ & $\begin{array}{r}83.9 \% \\
(\mathrm{~N}=313)\end{array}$ & $\begin{array}{r}85.1 \% \\
(\mathrm{~N}=1,273)\end{array}$ \\
\hline & $\begin{array}{l}80.2 \% \\
\text { TOTAL }\end{array}$ & $(\mathrm{N}=1,759)$ & $74.7 \%$ \\
\hline
\end{tabular}

Note: $\mathrm{N}$ represents the total number of civil and uncivil reader comments posted in PDI's news website and official Facebook page within the study's archiving timeframe.

\section{The Climate of Incivility in PDI's Social Media Environment}

Even though studies about online incivility in deliberative intercourse is not new (e.g., Anderson et al., 2014; Coe, Kenski, \& Rains, 2014; Diakopoulos \& Naaman, 2011; Rosner \& Kramer, 2016), there is a dearth in scholarly research examining incivility in the context of local online discourse. My study on the incidence of incivility in the reader comments field of PDIs news website and official Facebook page is the first local study that offers an evidence-based description of the landscape of incivility in two specific local public discourse environments. While my inventory made use of the forms of incivility identified and synthesized from extant literature, in further moving local research on incivility forward, I am reiterating the need for a more indigenous conceptualization of incivility and its various forms. A locally-grounded definition of incivility would heighten the contextual strength of its conceptual nuances.

My content analysis of the seven top-trending news articles representing a seven-day constructed week reveals that character assassination is the most popular form of incivility in PDI's news website and official Facebook page, that it is also typically present across all reader comment response levels, and that it is commonly invoked across all targets. Apart from character assassination, other popular forms of incivility include stand assassination, mockery, and name-calling.

Overall, uncivil comments commonly contain uncivil forms from the utterance dimension. This is probably due to the wide availability of reusable and recyclable uncivil utterance content as well as the ease of coming up with uncivil utterance comments. While discursive forms of incivility are not as common, threats to person and threats to freedom of speech and expression still exist in PDI's reader comments field. 
Offhand, while forms of incivility from the utterance dimension can be considered more insipid than forms of incivility from the discursive dimension, the predominant existence of uncivil elements from the utterance dimension across all comment levels provides evidence that these forms of incivility do generate further incivility. Indeed, the popular forms of incivility are replicated across the three comment levels. This finding provides support to the argument that incivility spirals into incivility (San Pascual, 2019) as the forms of incivility are replicated across the comment levels.

These uncivil comments are most likely other-directed and not an interpersonal attack on others within the discussion forum, which contradicts Rowe's (2015) findings that instances of uncivil comments on Washington Post's website and Facebook page were significantly more interpersonally directed at other commenters in the discussion thread. Perhaps sociocultural factors, such as Filipino's commonly accommodative behavior, could be at play in this situation other than anonymity. Further studies should be conducted to explore how sociocultural dynamics may influence online uncivil behavior.

Examining the timeline of uncivil posting within the study's archiving timeframe, uncivil comments that contain the most popular forms of incivility are usually generated within the first four hours of the reviewed articles' online publication. Uncivil posting that invokes the most popular forms of incivility typically peaks during the first and third hours, commonly diminishes thereafter before peaking again around the 13th hour, then diminishes and moves at a fairly systematic pattern until the 24th hour. The height of uncivil posting during the first three hours may coincide with the reviewed articles' online rate of dissemination. The ubiquity of access to digital technology (Lievrouw \& Silverstone, 2006) makes for faster and wider online dissemination and consumption of news and the interactivity (Lievrouw \& Silverstone, 2006) that social media platforms offer makes commenting instantly possible as readers come across trending news stories. This finding also offers a direction for further studies to explore the individual, social, political, and cultural factors that influence incivility's temporal pattern.

Incivility is commonplace in PDI's social media environment. Based on the articles reviewed, the density of incivility is at least $60 \%$. Hence, at best, only about $40 \%$ of comments can be classified as civil. Statistical tests show that there is generally higher density of incivility in PDI's news website compared to its official Facebook page, which may be attributed to the more anonymous comments section that the website has. This is consistent with Rowe's (2015) comparison of the incidences of incivility in 
reader comments on Washington Post's website and its official Facebook page wherein Washington Post's website has significantly more instances of uncivil comments than its Facebook page. As discussion participants are identified with their Facebook identity when they comment through Washington Post's official Facebook Page in contrast with the unregistered participants in the Post's website, Rowe (2015) attributed the difference in occurrence of uncivil communication behavior on the reader anonymity that the news website affords which minimizes commenter accountability for the posts made in that platform.

Findings reveal that the volume of reader comments does not determine the environment's incivility density. While the analyzed PDI articles' Facebook posting generated more reader comments than their website publication, incivility density is higher in $P D I$ 's news website than in its official Facebook page. This finding provides support to the online disinhibiting effect of anonymity that is typically more present in news websites than on Facebook (Hille \& Bakker, 2014; Rowe, 2015). Moreover, the more anonymous environment in $P D I$ 's news website may create deindividuation effect among online discourse participants, which further amplifies online disinhibited behaviors.

Apart from attributing higher incivility density to greater anonymity, quite possibly, website commenters may have read a greater portion of the article or they may have more access to the article's background, which may then allow them to sharpen their stance, and which may consequently lead them to more aggressive manners of expressing their opinion. In contrast, because of the free Facebook access that telecommunications companies offer to their subscribers, which only allows subscribers to view the title, accompanying photo, and/or the first sentence of posted news articles, a considerable number of Facebook comments may have been made on the basis of the article title and photo alone, and not on the basis of reading the full text of the article (access to which is beyond the free Facebook promo). Thus, Facebook commenters may feel less comfortable in articulating burlier opinions.

Generally, then, over half of the comments in PDI's social media environment would contain uncivil elements, primarily from the utterance dimension and commonly character assassination, would be directed at others not involved in the discussion, and would typically be posted within the first four hours of the top trending news article's online publication, peaking up again at around the 13th hour, then diminishes and moves at a relatively systematic pattern from the 14th hour of the news article's online publication. 
Findings therefore reveal that uncivil remarks in PDI's social media environment do not predestine silence, which confirms a conclusion that incivility may stimulate some individuals to participate in an ongoing uncivil discussion (San Pascual, 2020). The question now, however, is whether these uncivil comments actually contributed to deliberative conversation or were just mere uncivil remarks. Papacharissi (2004) argued that incivility is not a mere manifestation of impoliteness, rather, incivility threatens democracy as it compromises deliberative discussion. While incivility may not automatically lead to silence and while uncivil elements may even prompt some individuals to jump in the discussion (San Pascual, 2020), if uncivil remarks are merely placed there to attack a person's character, attack a person's stand, mock, or name-call, then uncivil comments may not be facilitating a deliberative exchange. In a sense, this makes incivility a threat to democracy, as Papacharissi (2004) pointed out. These days, however, it has come to a point where uncivil remarks are not mere impoliteness, rather, uncivil elements have been weaponized and this is where the danger of incivility comes in (Chen, 2017).

It is thus recommended that future studies examine the presence and extent of deliberation that occur in posts that contain uncivil elements. Chen (2017), for instance, in her study of Fox News, Huffington Post, NBC News Digital, The New York Times, and USA Today, found that incivility and deliberation can coexist. Then again, Chen (2017) wrote,

This is also not to say that incivility should be trumpeted. It should not. There is no doubt in my mind that a deliberative comment would be improved if it did not include an insult or a profanity. Yet, as a pragmatist, I would rather the comment contain some incivility than that deliberative thought not get aired in the public sphere. (p. 117)

Scholars interested in further examining the landscape of incivility in local social media environments may also examine the interaction of civil or uncivil reader comments with the topic and issue position of the news articles. Future research may also cover other popular public discourse environments and may also incorporate a wider pool of social media content for analysis.

Apart from the consequence of incivility on public discourse participation or withdrawal, future studies may also examine how uncivil social media exchanges could have far-reaching consequences on the intersection of public opinion and stability of institutions. For instance, the results of the experiments conducted by Diana C. Mutz and Byron Reeves (2005) uncovered that uncivil exchanges in a televised political debate erode 
political trust, at least in the immediate term, and low levels of political trust may compromise the ability of political institutions to govern more efficiently.

Moving forward, news website and Facebook reader comments moderation policies may be explicitly directed to address the popular forms of incivility and should also endeavor to remind the online public to practice mutual respect. While PDI has yet to publish its comments moderation policy online, a cursory examination of the reader comments section of $P D I$ 's news website reveals that some reader comments have indeed been deleted or are under review. This means that $P D I$ has a moderation policy in place and practices some form of editorial moderation. Then again, the same editorial moderation cannot be said for PDIs official Facebook page.

Initially, the comments posted on the comments field of Philippine news websites were generally unmoderated (or not as fiercely moderated) but news websites had the option of taking out comments that they deem odious and those that were flagged as offensive. Interestingly, as early as April 2013, Rappler, a social news network, published its Comment Moderation Policy containing a six-point guideline on how to "ensure the quality" of public discourse, which covers directives on staying on point and nontolerance of obscenities, hate, personal attacks, spam, porn, illegal materials, and smear campaigns ("Comment Moderation Policy," 2013). However, despite the presence of this policy, there have been incidences of vitriolic posting and exchanges in Rappler's comments section. In response to this, Rappler launched its \#NoPlaceForHate Campaign on 26 August 2016 to make the comments section a place free from incivility by implementing a sterner moderation of reader comments to create, safeguard, and protect its reader comments field from commenters who seek to harass, silence, and tame ("\#NoPlaceForHate: Change comes to Rappler's comments thread," 2016). As such, Rappler warned that editors would expunge "crude and disrespectful posts" and "comments that violate standards of civility" such as "comments that curse, trash, degrade, humiliate and intimidate" (para. 3)

In the international arena, various online news websites have employed measures to help them manage the occurrence of incivility in their reader comments section. For example, the New York Times only allows comments from commenters who use their real names and also intensively moderates the comments posted (Leavitt \& Peacock, 2014). The Huffington Post also only allows comments from registered Facebook users (Leavitt \& Peacock, 2014). On the extreme end, Popular Science shut down its comments section (Leavitt \& Peacock, 2014). 
Regarding the official Facebook page of news websites, Facebook itself has published its community standards:

Every day, people use Facebook to share their experiences, connect with friends and family, and build communities. We are a service for more than two billion people to freely express themselves across countries and cultures and in dozens of languages.

We recognize how important it is for Facebook to be a place where people feel empowered to communicate, and we take seriously our role in keeping abuse off our service. That's why we've developed a set of Community Standards that outline what is and is not allowed on Facebook. Our policies are based on feedback from our community and the advice of experts in fields such as technology, public safety and human rights. To ensure that everyone's voice is valued, we take great care to craft policies that are inclusive of different views and beliefs, in particular those of people and communities that might otherwise be overlooked or marginalized. (“Community Standards," n.d., para. 1-2)

Facebook's set of Community Standards includes directives on violence and criminal behavior (e.g., conducting harm and publicizing crime; fraud and deception), safety (e.g., bullying and harassment; human exploitation; privacy violations and image privacy rights), objectionable content (e.g., hate speech; violent and graphic content; adult nudity and sexual activity; sexual solicitation), integrity and authenticity (e.g., misrepresentation; cybersecurity; false news), reporting intellectual property, and contentrelated requests. Behaviors such as bullying or harassment, direct threats, and sexual violence and exploitation are considered Community Standards violations. As such, comments posted on the official Facebook page of $P D I$ and other news organizations are covered by Facebook's Community Standards on safe online behavior:

Our Community Standards apply to everyone, all around the world, and to all types of content. They're designed to be comprehensive - for example, content that might not be considered hateful may still be removed for violating a different policy. We recognize that words mean different things or affect people differently depending on their local 
community, language, or background. We work hard to account for these nuances while also applying our policies consistently and fairly to people and their expression. In the case of certain policies, we require more information and/or context to enforce in line with our Community Standards.

People can report potentially violating content, including Pages, Groups, Profiles, individual content, and comments. We also give people control over their own experience by allowing them to block, unfollow, or hide people and posts.

The consequences for violating our Community Standards vary depending on the severity of the violation and the person's history on the platform. For instance, we may warn someone for a first violation, but if they continue to violate our policies, we may restrict their ability to post on Facebook or disable their profile. We also may notify law enforcement when we believe there is a genuine risk of physical harm or a direct threat to public safety.

Our Community Standards are a guide for what is and isn't allowed on Facebook. It is in this spirit that we ask members of the Facebook community to follow these guidelines. (“Community Standards," n.d., para. 9-11)

While Facebook continues to maintain that it is not a media company but a tech company, incidental news exposure via Facebook link to news is emerging as the primary driver of traffic to news website and the public are increasingly reliant on Facebook as a news prompt (David, San Pascual, \& Torres, 2019; Mitchel, Kiley, Gottfried, \& Guskin, 2013). Indeed, Yonghwan Kim, Hsuan-Ting Chen, and Homero Gil de Zuñiga (2013) found that incidental news exposure has a significant and positive relationship with online and offline political participation. Thus, even with its set of community standards, the apparent growth in the incidence of incivility on Facebook prompted serious calls for Facebook to make a more aggressive action to safeguard the integrity of the space as an arena for truthful information and a safe place for discursive interaction (i.e., Bell, 2016).

Apart from comment moderation policies and regardless of a news agencies' readership profile, new media literacy education should be ultimately expanded to include modules on civil online public discourse participation and on the democratic consequences of uncivil engagement 
in the online public discourse arena. Furthermore, values formation should be strengthened not only to inculcate good manners and right conduct but should likewise cultivate the value of respect and tolerance of our human differences, both offline and online.

\section{Acknowledgments}

This work was funded by the University of the Philippines Enhanced Creative Work and Research Grant (ECWRG 2017-1-028).

The author would like to acknowledge the research assistance of Alyssa P. Viquiera, Bianca Nicole C. Urrutia, Bea Mae S. Caloyloy, and Queenie Rose E. Chico. 


\section{References}

\#NoPlaceforHate: Change comes to Rappler's comments thread. (2016, 26 August). Rappler. Retrieved from https://www.rappler.com/views/143975-no-place-for-hate-change-comes-to-rapplercomments-thread.

Anderson, A. A., Brossard, D., Scheufele, D.A., Xenos, M.A., \& Ladwig, P. (2014). The "nasty effect": Online incivility and risk perceptions of emerging technologies. Journal of Computer-Mediated Communication, 19(3), 373-387. DOI:10.1111/jcc4.12009

Antoci, A., Delfino, A., Paglieri, F., Panebianco, F., \& Sabatini, F. (2016). Civility vs. incivility in online social interactions: An evolutionary approach. Munich personal RePEc archive paper no. 72454.

Bell, E. (11 November 2016). Facebook can no longer be 'I didn't do it' boy of global media. Columbian Journalism Review. Retrieved from https://www.cjr.org/tow_center/facebook_zuckerberg_trump_ election.php

Brooks, D. J., \& Geer, J. G. (2007). Beyond negativity: The effects of incivility on the electorate. American Journal of Political Science, 51(1), 1-16.

Burns, N., Schlozman, K.L., \& Verba, S. (2001). The private roots of public action: Gender, equality, and political participation. Cambridge, MA: Harvard University Press.

Chang, J. (Fall 2008). The role of anonymity in deindividuated behavior: A comparison of deindividuation theory and the social identity model of deindividuation effects (SIDE). The Pulse, 6(1): 1-8. Retrieved from https://www.baylor.edu/content/services/document.php?id=77099

Chen, G. M. (2017). Online incivility and public debate: Nasty talk. New York, NY: Springer.

Chen, G. M., \& Lu, S. (2017). Online political discourse: Exploring differences in effects of civil and uncivil disagreement in news website comments. Journal of Broadcasting \& Electronic Media, 61(1), 108125.

Coe, K., Kenski, K., \& Rains, S. A. (2014). Online and uncivil? Patterns and determinants of incivility in newspaper website comments. Journal of Communication, 64(4), 1-22. DOI:10.1111/jcom.12104

Comment moderation policy. (2013, 26 April). Rappler. Retrieved from https://www.rappler.com/aboutrappler/about-us/27506-comment-moderation-policy

Community standards. (n.d.). Retrieved from https://www.facebook.com/communitystandards/

Company. (n.d.). Retrieved from https://www.inquirer.com.ph/company

Dahlgren, P. (2009). Media and political engagement: Citizens, communication, and democracy. New York: Cambridge University Press.

David, C. C., San Pascual, M. R. S., \& Torres, M. E. (2019). Reliance on Facebook for news and its influence on political engagement. PLOS ONE 14(3). Retrieved from https://doi.org/10.1371/journal. pone. 0212263

Diakopoulos, N., \& Naaman, M. (2011). Towards quality discourse in online news comments. CSCW 2011, 19-23 March 2011, Hangzhou, China.

franzke, a. S., Bechmann, A., Zimmer, M., Ess, C.M., \& the Association of Internet Researchers. (2020). Internet research: Ethical guidelines 3.0. https://aoir.org/reports/ethics3.pdf .

Gervais, B. T. (2014). Following the news? Reception of uncivil partisan media and the use of incivility in political expression. Political Communication, 31(4), 564-583. DOI: 10.1080/10584609.2013.852640 
Herbst, S. (2010). Rude democracy. Philadelphia, PA: Temple University Press.

Hille, S., \& Bakker, P. (2014). Engaging the social news user: Comments on news sites and Facebook. Journalism Practice, 8(5), 563-572. DOI: 10.1080/17512786.2014.899758

History. (n.d.). Retrieved from https://www.inquirer.com.ph/company/history

Inquirer.net traffic statistics. (2018, January 2). Retreived from 2018. https://www.alexa.com/siteinfo/ inquirer.net

Kim, Y., Chen, H. T., \& de Zuñiga, H. G. (2013). Stumbling upon news on the Internet: Effects of incidental news exposure and relative entertainment use on political engagement. Computers in Human Behavior, 29(6), 2607-2614. DOI: 10.1016/j.chb.2013.06.005

Krippendorf, K. (2004). Content analysis: An introduction to its methodology. 2nd ed. California, London, and New Delhi: Sage Publications.

Kwon, K. H., \& Cho, D. (2015). Swearing effects on citizen-to-citizen commenting online: A large-scale exploration of political versus nonpolitical online news sites. Social Science Computer Review, 35(1), 84-102.

Leavitt, P., \& Peacock, C. (2014, 4 August). Civility, engagement, and online discourse: A review of literature. Washington DC: University of Arizona National Institute for Civil Discourse.

Lievrouw, L. A. \& Livingstone, S. (2006). Handbook of new media: Social shaping and social consequences of ICTS (Updated student edition). London; Thousand Oaks, California; New Delhi: Sage Publications.

McHugh, M. L. (2012). Interrater reliability: The kappa statistic. Biochemica Media, 22(3), 276-282. Retrieved from https://www.ncbi.nlm.nih.gov/pmc/articles/PMC3900052/.

Mitchell, A., Kiley, J, Gottfried, J., \& Guskin, E. (24 October 2013). The role of news on Facebook: Common yet incidental. Retrieved from https://www.journalism.org/2013/10/24/the-role-of-news-onfacebook/

Montgomery, K., Kane, K., \& Vance, C.M. (2004). Accounting for differences in norms of respect: A study of assessments of incivility through the lenses of race and gender. Group \& Organization Management, 29(2), 248-268.

Mutz, D. C. \& Reeves, B. (2005). The new videomalaise: Effects of televised incivility on political trust. American Political Science Review, 99(1), 1-15

Neuendorf, K. A. (2002). The content analysis guidebook. California, London, New Delhi: Sage Publications. Noelle-Neumann, E., \& Petersen, T. (2004). The spiral of silence and the social nature of man. In L. L. Kaid (Ed.) Handbook of political research (pp. 339-355). New Jersey and London: Lawrence Earlbaum Associates, Publishers.

Our market. (n.d.). Retrieved from https://www.inquirer.com.ph/company/our_market

Papacharissi, Z. (2004). Democracy online: Civility, politeness, and the democratic potential of online political discussion groups. New Media \& Society, 6(2), 259-283.

Pernia, E. E. (2004). Communication research in the Philippines: Issues and methods. Quezon City: The University of the Philippines Press.

Rosner, L. \& Kramer, N. C. (2016). Verbal venting in the social web: Effects of anonymity and group norms on aggressive language use in online comments. Social Media + Society, 2(3), 1-13. DOI: $10.1177 / 2056305116664220$ 
Rowe, I. (2013, September). Civility 2.0: A comparative analysis of incivility in online political discussion. Paper presented at the Elections, Public Opinion, and Parties Conference, University of Lancaster, UK.

Rowe, I. (2015). Civility 2.0: A comparative analysis of incivility in online political discussion. Information, Communication, and Society, 18(2), 121-138.

San Pascual, M. R. S. (2019, May). Spiral of civility and incivility. Paper presented at the 2019 Annual International Communication Association Conference, Washington, DC, USA.

San Pascual, M. R. S. (2020, May). Paradoxes of civility and incivility: How civil or uncivil online discussion of support or dissent influence online opinion articulation or concealment. Paper presented at the 2020 Annual International Communication Association Conference, Virtual Conference.

Sapiro, V. (1999, July). Considering political civility historically: A case study of the United States. A paper presented at the Annual Meeting of the International Society for Political Psychology, Amsterdam, The Netherlands.

Sobieraj, S., \& Berry, J.M. (2011). From incivility to outrage: Political discourse in blogs, talk radio, and cable news. Political Communication, 28(1), 19-41. DOI: 10.1080/10584609.2010.542360

Stryker, R., Conway, B., \& Danielson, J. T. (2014). What is political incivility? Paper presented at the 2014 National Communication Association Convention, Chicago, Illinois, USA.

Suler, J. (2004). The online disinhibition effect. Cyberpsychology \& Behavior, 7(3), 321-325.

Yun, G. W., \& Park, S. Y. (2011). Selective posting: Willingness to post a message online. Journal of Computer-Mediated Communication, 16(2), 201-227.

\section{Endnotes}

${ }^{1}$ Generated through Random.Org's random sequence number generator

MA. ROSEL S. SAN PASCUAL is a full-time faculty member of the Department of Communication Research of the College of Mass Communication, University of the Philippines Diliman. She has a PhD in Communication from the University of the Philippines Diliman, an MA in Communications and New Media from the National University of Singapore, and a Masters in Development Economics from the University of the Philippines Diliman. Her research interests include new media, online discourse, and transnational migration and family communication. (corresponding author: mssanpascual@up.edu.ph) 
